\title{
Article
}

\section{Growing syntax: The development of a DP in North Germanic}

Börjars, K, Vincent, N and Harries, Pauline

Available at http://clok.uclan.ac.uk/19758/

Börjars, K, Vincent, N and Harries, Pauline ORCID: 0000-0001-5069-9946 (2016) Growing syntax: The development of a DP in North Germanic. Language, 92 (1). e1-e37. ISSN 0097-8507

It is advisable to refer to the publisher's version if you intend to cite from the work. http://dx.doi.org/10.1353/lan.2016.0002

For more information about UCLan's research in this area go to http://www.uclan.ac.uk/researchgroups/ and search for < name of research Group>.

For information about Research generally at UCLan please go to http://www.uclan.ac.uk/research/

All outputs in CLoK are protected by Intellectual Property Rights law, including Copyright law. Copyright, IPR and Moral Rights for the works on this site are retained by the individual authors and/or other copyright owners. Terms and conditions for use of this material are defined in the policies page.

\section{CLoK}

Central Lancashire online Knowledge www.clok.uclan.ac.uk

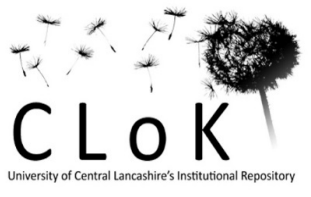




\section{PROJECT MUSE}

Growing syntax: The development of a DP in North Germanic

Kersti Börjars, Pauline Harries, Nigel Vincent

Language, Volume 92, Number 1, March 2016, pp. e1-e37 (Article)

Published by Linguistic Society of America

DOI: https://doi.org/10.1353/lan.2016.0002

$\Rightarrow$ For additional information about this article https://muse.jhu.edu/article/612050 


\section{HISTORICAL SYNTAX}

\section{Growing syntax: The development of a DP in North Germanic}

\section{KERSTI BÖRJARS}

The University of Manchester

\author{
Pauline Harries \\ University of \\ Central Lancashire
}

\author{
Nigel VinCENT \\ The University of \\ Manchester
}

Grammaticalization as standardly conceived is a change whereby an item develops from a lexical to a grammatical or functional meaning, or from being less to more grammatical. In this article we show that this can only be part of the story; for a full account we need to understand the syntactic structures into which grammaticalizing elements fit and how they too develop. To achieve this end we consider in detail the history of definiteness marking within the noun phrase in North Germanic, and in particular in Faroese. We show how this change requires us to distinguish between projecting and nonprojecting categories, and how a category can emerge over time and only subsequently develop into a head with its own associated functional projection. The necessary structure, rather than being intrinsic to an aprioristic universal grammar, grows over time as part of the grammaticalization process. We suggest that this in turn argues for a parallel correspondence theory of grammar such as the one adopted here, LEXICAL-FUNCTIONAL GRAMMAR, in which different dimensions of linguistic structure can change at different rates.*

Keywords: emerging structure, Old Norse, Faroese, DP, structural persistence

1. InTRODUCTION. Grammaticalization is generally described as a process whereby lexical content is lost and replaced by more grammatical content. An example is provided in 1a, which shows the Swedish verb komma with a future meaning. The original, and still existing, meaning of the verb is 'come', as illustrated in $1 b .{ }^{1}$

(1) a. Det kommer att snöa i morgon.

it come.PRS INF SnOw.INF tomorrow

'It will snow tomorrow.'

b. Vår katt kommer alltid hem tidigt på morgonen.

our cat come.PRS always home early on morning.DEF

'Our cat always comes home early in the morning.'

This can be distinguished from another type of grammaticalization, which involves a construction as a 'template' made up of slots and categories. ${ }^{2}$ This kind of change can be illustrated by the distribution of the verb-first pattern in the apodoses of hypothetical sentences in various Germanic languages, as illustrated for German in 2a, for Swedish in $2 \mathrm{~b}$, and for English in 2c.

\footnotetext{
* Versions of this article have been presented at four conferences: the 2011 meeting of the Linguistics Association of Great Britain (Manchester), New Reflections on Grammaticalisation 5 (Edinburgh), LFG2012 (Bali), and SLE2012 (Stockholm), and we are grateful to all four audiences for their comments, especially David Adger, Lars Heltoft, Joan Maling, and Rachel Nordlinger. For comments on an initial written version, we are grateful to Ulla Stroh-Wollin, who made valuable suggestions, though she approaches the data from a different theoretical perspective. Two anonymous referees provided comments that have led to radical improvements.

${ }^{1}$ Throughout this article, we do not provide a detailed glossing of examples, but only give those features that are relevant to the discussion. The following abbreviations are used: COMP: complementizer, DEF: definite, DEM: demonstrative, F: feminine, GEN: genitive, INDF: indefinite, INF: infinitival marker, M: masculine, N: neuter, PL: plural, POSS: possessive, PREP: preposition, PRS: present, REFL: reflexive, REL: relativizer, STR: strong, and WK: weak. Where the idiomatic translation is obvious from the glossing, it is not provided separately.

${ }^{2}$ We are using 'construction' in the nontechnical sense here. Within CONSTRUCTION GRAMMAR, the bold element in 1a would also be a 'construction'.
} 
(2) a. Ändern sie das Testament, dann tritt eine neue Rechtslage ein. change.PRS they the testament then set.PRS a new legal.situation in

'If they change the testament, a new legal situation obtains.'

b. Räknar man även barnen, blir siffran avsevärt count.PRS one even child.DEF.PL become.PRS number.DEF considerably högre.

higher

'If children are also counted, that number increases substantially.'

c. Had they left home earlier, they wouldn't have missed the train.

The difference between the languages lies in the extent to which the pattern has been grammaticalized, as discussed in Hilpert 2010, from which examples $2 \mathrm{a}$ and $2 \mathrm{~b}$ are taken. In Swedish and the other modern Scandinavian languages, it is found in all registers and with all verbs as a systematic alternative to the pattern where there is an overt conjunction equivalent to English if (Swedish om, Danish hvis) and the verb follows the subject. By contrast, in German, to quote Hilpert (2010:200), 'the construction tends to occur in formal written contexts of stating regularities or law-like procedures'. In English, it has become frozen and only occurs with the modals or auxiliaries had, should, and were; elsewhere the structure with if is required. Such conjunctions are in turn themselves the product of the first kind of grammaticalization: om and if are cognate and derive from oblique case forms of a noun meaning 'doubt', while hvis is in origin an interrogative pronoun. Hence, for hypotheticals in these languages the choice is between the grammaticalized structure and the grammaticalized conjunction or complementizer.

In this article, we discuss a third type of grammaticalization, which contains ingredients of both of these types in that the change we study involves both the development of a grammaticalized meaning in one element, and this grammaticalized meaning becoming associated with a particular structural position. We argue here that the grammaticalization that results in one item becoming a dedicated marker of definiteness also leads to, first, the development of a category D, and subsequently the emergence of a full DP projection.

We start by introducing the theoretical architecture used for our analysis ( $(2)$. In $\S 3$ we outline some analyses that are similar to our own in that they assume that syntactic structure, and in particular structure involving functional projections, can develop over time. We then present data and analysis of the three time periods we consider: Old Norse ( $\$ 4)$, early Faroese ( $\$ 5)$, and Present-Day Faroese ( 6 ). The reason for the focus on Faroese is partly the fact that there has been little discussion in the literature of earlier stages of Faroese. Its development of definiteness is also of special interest, however, in particular the so-called 'double definiteness', in relation to the language it originates from-Old Norse - and the language that influenced it most in recent times-Danish. In $\S 7$ we draw together our conclusions.

2. TheORETICAL ASSUMPTIONS. In some theoretical frameworks, structure is assumed to be universally present in all languages, or stages of languages, regardless of surface manifestation. Within such an approach, the development sketched in $\S 1$ would not involve any change in structure, just to the properties of lexical items and the movement these properties may give rise to, as well as the distribution of zero elements. In our view, structure is not universal; rather, we assume that structural patterns such as those illustrated in 2 come into existence, or 'grow', over time in different ways in different languages. One thing in common between our approach and that espoused by many advocates of universal structure, however, is the belief that it is the task of general linguistic theories to accommodate the facts of change as well as those derivable from 
purely synchronic analysis. Grammaticalization is a label for one class of facts that such theories need to respond to, and hence the expression 'grammaticalization theory', which is frequently encountered in the literature, represents what philosophers call a 'category mistake'. On the view taken in this article, grammaticalization involves the development both of overt function words and of syntactic structure. One question for linguistic theory is then: How can such patterns of change be accommodated within current theoretical frameworks? We argue that the parallel correspondence architecture of LEXICAL-FUNCTIONAL GRAMMAR (LFG), in combination with its approach to the representation of structure, makes it eminently suited to this task.

There are four assumptions about the representation of grammar that are crucial to our analysis:

(i) Different dimensions of linguistic information are represented independently, with formal mappings connecting them.

(ii) A language can be configurational or nonconfigurational.

(iii) Functional projections are assumed only where functional information is associated with an overt element in a specific structural position.

(iv) A distinction can be made between NP languages and DP languages.

The assumption in (i) is central to LFG (Bresnan 2001, Dalrymple 2001, Falk 2001); different types of information associated with any linguistic element are represented in separate dimensions, each of which has its own formalism and organizational principles. The different dimensions are then linked by mapping rules that do not assume that relations are exclusively one to one. We can illustrate this with respect to two dimensions that will be of particular interest to us in this article: the one that captures information about categories and constituent structure - $\mathrm{c}$-structure - and the one that represents functional information such as grammatical relations, tense, and definitenessf-structure. C-structure is represented as labeled constituent trees, whereas f-structure takes the shape of attribute-value matrices (AVMs). A simple example is provided in 3.

(3) C-structure and f-structure in LFG

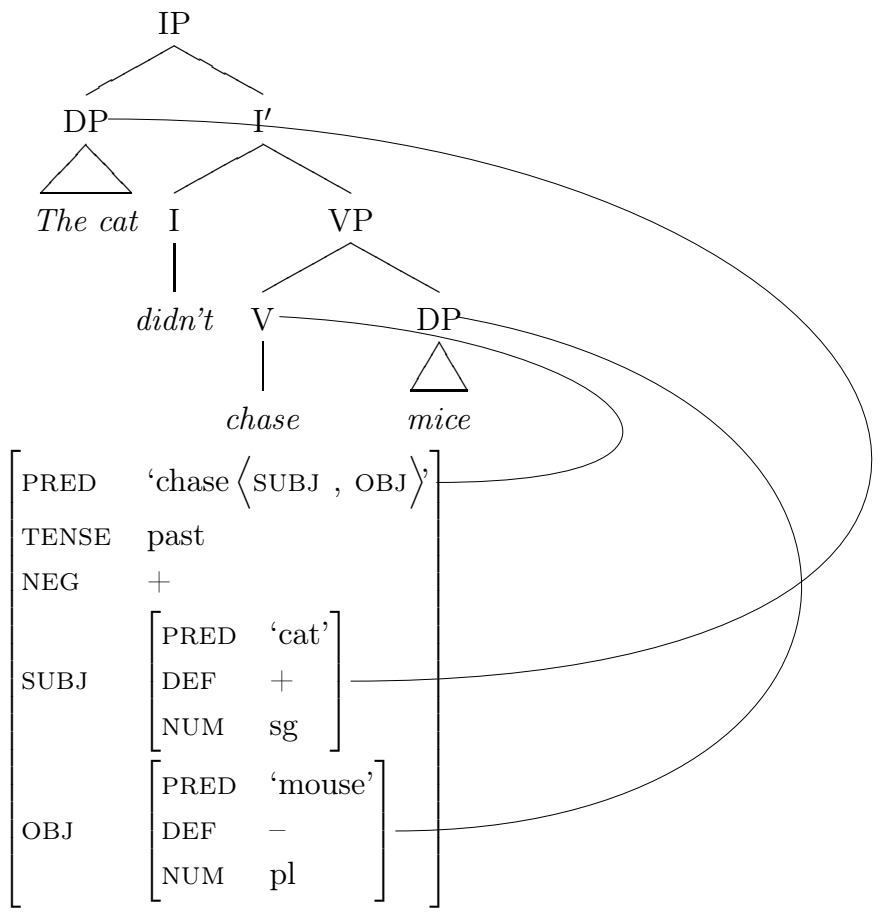


The curved lines indicate mapping principles that ensure that the cat is associated with the SUBJECT function, that the V supplies the PRED feature of the whole sentence, and so on. Every node in the c-structure - including those associated with the lexical items - is associated with some f-structure, and the f-structure contributed by each node combines monotonically to form the f-structure of the whole. In a highly configurational language like English, the mapping to grammatical relations such as SUBJ and OBJ is structure-based. The DP the cat is identified as the subject because it occurs in the Spec-IP position. This is formalized in LFG as annotated phrase-structure rules, exemplified in 4.

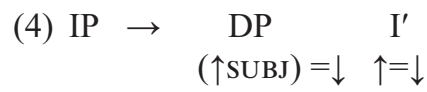

The up-arrow in 4 refers to the $\mathrm{f}$-structure associated with the mother node-IP - and the down-arrow to the f-structure associated with the node itself. The annotation under the DP node can then be read as 'the f-structure associated with the IP contains a feature SUBJ, and the value of that feature is the f-structure associated with the DP'. The $\uparrow=\downarrow$ under the $I^{\prime}$ indicates that it shares its f-structure with the mother. This is typical of a head.

The architecture assumes further dimensions, for instance $\mathrm{m}$ (orphological)-structure, $\mathrm{a}$ (rgument)-structure, $\mathrm{p}$ (rosodic)-structure, and i(nformation)-structure. We do not make any reference to the formal analysis of any of these here, but refer to Asudeh \& Toivonen 2009 for a concise description of the dimensions and the connections between them. However, one assumption that will be of importance to our analysis is that informationstructural factors need not be captured through the positing of separate structural positions unless these are independently motivated, in which case so-called GRAMMATICALIZED DISCOURSE FUNCTIONS are assumed. We will see an example of this in our analysis of Old Norse.

A consequence of the parallel architecture is that historical change may take place in one dimension, but not in another; there can be change in form without an associated change in function and vice versa. In such instances, there would then also be a change in the mapping between the two dimensions. This distinguishes this approach from accounts of linguistic change within some other frameworks, as illustrated by a comparison with Roberts \& Roussou 2003 or van Gelderen 2004, where the changes in form and function are assumed to be more closely matched.

A number of authors have discussed the role of (ii) within LFG (Bresnan 1982, 2001, Kroeger 1993, Austin \& Bresnan 1996, Nordlinger 1998). A more subtle and accurate formulation of it would be that CERTAIN STRUCTURES within a language can be configurational or nonconfigurational. There are languages with near-complete nonconfigurationality, like Dyirbal (Dixon 1972), but frequently languages are referred to as nonconfigurational when there is simply no evidence of a VP, even though noun phrases may be fully configurational in the same language. For a nonconfigurational language, a highly articulated tree like 3 would not be appropriate, but a flatter tree, possibly with an exocentric category, would be assumed in LFG. In 5, we provide the structure assumed for a language lacking evidence for a VP. We take Latin to be an example of such a language (see for instance Jøhndal 2012).

(5)

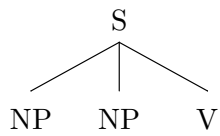

In a language for which a structure such as 5 is assumed, sUBJ would not be identified in terms of a c-structure position, but through its morphology, in particular its nomina- 
tive case. In LFG this is captured through a functional equation such as 6, which is assumed to be part of the grammar of the language (Bresnan 2001:111).

(6) $(\downarrow$ CASE $)=$ nom $\Rightarrow(\uparrow$ SUBJ $)=\downarrow$

The equation in 6 should be read as 'if the f-structure associated with this node contains a CASE feature with the value nom, then the f-structure associated with the mother of this node has a feature SUBJ with as its value the f-structure associated with this node'. Note that the phrase-structure rule that licenses the tree in 5 does not say anything about the functions of the NP constituents, and the equation in 6 does not refer to a structural position.

In this article, we are concerned with the configurationality of noun phrases and have nothing to say about clausal structure. We suspect, however, that there is a strong tendency for noun phrases to be more configurational than clauses in a language. In line with the LFG assumptions about the nature of c-structure, we assume that trees are neither exclusively binary branching nor exclusively endocentric.

With respect to (iii), counter to some syntactic frameworks, LFG takes a restrictive view of projecting functional categories. As we have seen in 6, in LFG, the functional information represented in $\mathrm{f}$-structure can be contributed not just by the syntax, but also by the morphology. ${ }^{3}$ Hence a syntactic functional projection is only assumed when it can be independently argued for; the overt marking of functional information is not sufficient on its own to justify a functional projection. Following Kroeger (1993:6-7) and Börjars and colleagues (1999), for instance, we assume that only when there is evidence that functional information is associated with a particular structural position is a functional projection motivated. In the English example in 3, it is the special behavior of finite auxiliaries that motivates the use of a functional node I. In the Scandinavian languages, the fact that finiteness is associated with second position in the clause would be evidence that the clause is headed by a functional category.

It has been assumed by, for instance, Szabolcsi (1987), Stowell (1989), and Longobardi (1994) that a referential noun phrase must be of category DP (or, in more recent approaches, the projection of some other functional category), so that an NP can only be nonreferential. In such an approach, if a definite article can be shown to have evolved, this is not associated with a structural change; it is just a new filler of an existing position. This is what Abraham and colleagues (2007:3) refer to as the "covert-to-overt-D hypothesis', which they contrast with the 'out of nothing-to-D hypothesis'. Our analysis falls within the latter category (though 'out of nothing' is not quite the right term); we assume that a distinction can be made between languages - or stages of languagesin which referential noun phrases are DPs and those in which they are NPs. Chierchia (1998) argues for this position on semantic grounds. Syntactic arguments for the distinction between NP languages and DP languages have been provided by a number of linguists, going back to Fukui 1986 and Fukui \& Speas 1986. More recently Bošković (2005, 2008, 2009), assuming a distinction between NP and DP languages, has attempted to show that this distinction correlates with a number of other properties of the noun phrase. Some of these can be relatively straightforwardly established on empirical grounds, such as 'syntactic discontinuity and free word order', but others rely on specific theoretical assumptions. In Bošković 2010, the generalizations are extended to include clausal properties, to show that an NP language is also likely to lack functional

\footnotetext{
${ }^{3}$ Other dimensions of information can also contribute f-structure information; for instance, in the Iron dialect of Ossetic, definiteness can be indicated solely by a leftward shift of stress within the noun phrase (Abaev 1949). For an analysis of such data within LFG, see Börjars \& Payne 2013.
} 
categories such as TP at the clausal level. In $\S 3$ we consider a number of analyses that have used the distinction to account for historical change.

Though the assumption that a language can be an NP language in the sense of allowing NPs to function as fully referential noun phrases chimes with our approach, it should be pointed out that the DP/NP analyses referred to above generally take the presence or absence of a syntactic definite determiner as sufficient evidence to establish what type the language is. As explained, we take a different approach and assume that a DP projection is motivated only when a functional feature, such as definiteness, is associated with a particular structural position. The exponence of this feature need not take the shape of a syntactic determiner. Conversely, a language might have a dedicated syntactic definiteness element, but if this element is not associated with a particular structural position, we would not assume a DP projection (see Toivonen 2003 on the role of nonprojecting categories in LFG). ${ }^{4}$

3. Previous accounts of the Development of Syntactic structure. In itself, the idea that functional categories and syntactic structure emerge together over a period of time is not new. In a classic paper, Kiparsky (1995) argued that in origin the IndoEuropean proto-language did not have complementizers and as a consequence did not have a CP projection. Rather, he suggests that the basic Indo-European clause is exocentric with two information-structurally privileged positions at the left edge and with no clausal embedding. This yields the structure in 7, a structure that over time transmutes into 8 as the category $\mathrm{C}$ emerges, by a process of grammaticalization.

(7) Indo-European clause structure (Kiparsky 1995:153)

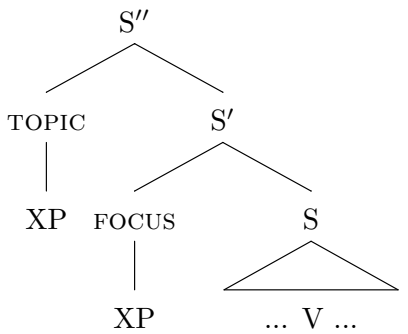

(8) Germanic clause structure (Kiparsky 1995:140)

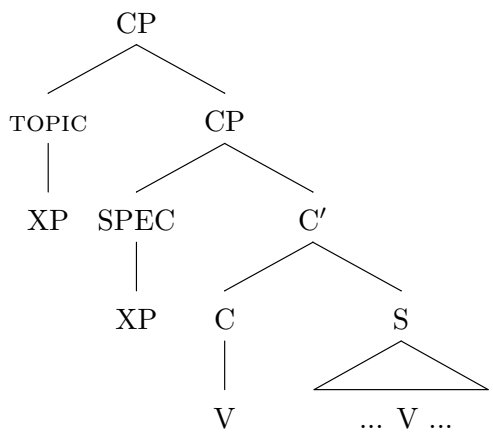

\footnotetext{
${ }^{4}$ Some authors assume there is a necessary connection. For instance, Van de Velde $(2010,2011)$ describes $\mathrm{D}$ as an 'emergent category', but does not develop the consequences for noun phrase structure further. Nonetheless, he concludes that a 'determiner projection' has emerged (2010:293). Similarly, without developing a detailed analysis, Perridon and Sleeman (2011) appear to assume implicitly that the emergence of a D is necessarily linked to a projection DP.
} 
On his account, the basic change that triggers the passage from 7 to 8 is the shift of subordinate clauses from adjunct to argument status, a development that is signaled by the emergence of complementizers to flag these new embeddings. These indeclinable complementizers ( pe, poet, er, som, etc.) have no inherited nominal content and thus can also come to host verbal elements, leading to the modern process of $\mathrm{V}$-to-C movement or its equivalent in nonderivational models of syntax.

An analogous argument is made for the emergence of prepositional phrases to replace many of the functions of the Latin case system in Vincent 1999. The difference in this instance is that Latin already had PPs, so the structure in and of itself is not new; what is new is rather the deployment of that structure in association with a grammaticalized preposition. Thus, reflexes of the Latin preposition de, in origin meaning 'down, away from, concerning', come to replace the genitive case as the marker of nominal and adjectival dependence in all of the Romance languages.

The idea that syntactic structure and functional categories emerge together over time has also been applied to nominal constituents, and a number of scholars have adduced evidence for the view that the functional head D and its DP projection have emerged over time. For instance, Vincent (1997) argues that the Romance languages develop a D system through the grammaticalization of the Latin deictic illum/-am to yield French $l e / a$, Italian il/la, Portuguese $o / a$, and kindred forms (cf. also Lyons 1999:322-33). Less frequently, in Romance, the same pattern develops from a distinct etymon, as with the Sardinian article su/sa from Latin ipsum/-am. Such emergence of identical configurational structures from diverse etymological sources within groups of related languages is akin to the different hypothetical complementizers if, om, hvis cited in $\S 1$ and the various embedding complementizers discussed by Kiparsky (1995).

A parallel between the development of definiteness in Romance and Germanic languages is drawn by Perridon and Sleeman (2011:7). They argue that in both families definiteness became associated not just with certain lexical elements, but also with a category D with a fixed prenominal position. Staying within Germanic, Lander and Haegeman (2013) argue - as we do, but from a different perspective - that Old Norse has NPs rather than DPs, and they show that some of the properties that Bošković links to NP languages do hold for Old Norse. ${ }^{5}$

Heltoft (2010) arrives at a similar conclusion though from a different theoretical perspective, analyzing the development of syntactic structure over time as an instance of GRAMMATION, a concept introduced by Andersen (2006). He argues that changes to the use of determiners and genitives in Danish provide evidence that the language has undergone a change from noun phrases being of the category NP to them becoming DPs. Although he does not provide details of the internal structure of the two types of phrases, he does show how a range of associated changes - morphological, syntactic, and semantic — can be understood in a framework within which the notion of paradigm has been extended to include the relation between syntactic constructions.

What none of the preceding NP-to-DP analyses does, which distinguishes them from our own account, is attempt to analyze the nature of the internal structure of the emer-

\footnotetext{
5 This is to be contrasted with accounts such as those by Stroh-Wollin (2009), who assumes that noun phrase structure has not changed between early and modern Scandinavian; Lohndal (2007), who proposes that the development between Old Norse and Modern Norwegian involves the development of a functional projection, nP; and Faarlund (2007), who concludes that the major change is that DP recursion was an option in Old Norse, but is not in modern Scandinavian, and Faarlund (2004, 2009), who argues that the development into modern Norwegian involves the loss of a functional projection R(eference)P (or rather this projection is described as being 'no longer active').
} 
gent DP and to focus on the mechanisms whereby that structure emerges. In this respect, perhaps nearest in spirit to our own endeavor is Himmelmann (1997:1), who observes: 'The central hypothesis is that syntactic structure can be the result of grammaticalisation processes, just as grammatical elements are; that it is not just article-like elements which arise this way, but also the categories and the constituent structure that characterises nominal expressions ${ }^{6}{ }^{6}$ Obviously, for such an account to hold water it is necessary to investigate in some detail the evidence for the internal structure of the nominal constituents at different historical moments, and it is this that we seek to do in the following sections.

\section{OLD NORSE.}

4.1. BaCKGround. Old Norse is a North Germanic language, although the exact naming and timing of its ancestor languages are subject to debate. There is a corpus of runic inscriptions in the Elder Futhark alphabet from before $500 \mathrm{AD}$, which has been convincingly argued since Antonsen 1967 to be most appropriately referred to as NorthWest Germanic: a language that is the common ancestor of both the Scandinavian and the North Sea West Germanic languages, from which East Germanic languages like Gothic had split off. ${ }^{7}$ A Common Nordic stage is posited from about 500 AD, which has been preserved in runic inscriptions in the Younger Futhark. From around 800 AD there is evidence of an eastern and a western variety of the North Germanic language, with many more sources existing for the former, generally referred to as Old Norse. ${ }^{8}$ It is from this variety that Icelandic, Faroese, and Norwegian descend, whereas the East Scandinavian branch developed into Swedish and Danish. ${ }^{9}$ The early stages of both the eastern and western branches have been preserved in the form of runic inscriptions, but since the twelfth century also in the form of written texts. Since the former are more restricted and formulaic, though we make occasional reference to runic data, our focus is on the nonrunic material. The general theoretical claim we want to make applies to the development of all Scandinavian languages and we refer to other varieties, but we use the development from Old Norse to Faroese to illustrate, and hence most of our illustrations come from Old Norse as the ancestor of Faroese.

4.2. Definiteness markers. Apart from the marking on adjectives, to which we return in $\S 4.3$, there are four elements involved in definiteness marking in Old Norse: free (h)inn, often translated as 'yonder', but whose general distribution at this stage is as an adjective definiteness marker; bound -inn; distal demonstrative sá (M.SG.NOM, sú in F.SG.NOM and pat in N.SG.NOM), also used as an adjective definiteness marker; and proximal demonstrative sjá (M.SG.NOM and petta in N.SG.NOM). ${ }^{10}$

\footnotetext{
${ }^{6}$ Our translation from the German original: 'Die zentrale Hypothese besagt, daß syntaktische Struktur ebenso Ergebnis von Grammatikalisierungsprozessen ist wie Grammatische Elemente, daß also in einem solchen Prozeß nicht nur die artikelähnliche Elemente entstehen, sondern zugleich auch die für nominale Ausdrücke charakteristischen syntaktischen Kategorien und Konstituentenstrukture.'

7 This stage is still sometimes referred to as Proto-Scandinavian (e.g. Roehrs \& Sapp 2004, Stroh-Wollin 2009).

${ }^{8}$ For an excellent brief summary of the stages of early Scandinavian based largely on Nielsen 1989, see Lander \& Haegeman 2013. Though Old Icelandic and Old Norwegian can be distinguished, we follow Lander and Haegeman and many others and use Old Norse.

${ }^{9}$ Norwegian Bokmål was subject to substantial influence from Danish from the sixteenth to the nineteenth centuries. Old Gutnish is sometimes distinguished as a separate third branch of East Scandinavian.

${ }^{10}$ We use 'bound marker' to refer to -inn throughout in order to avoid a discussion of whether it is a clitic or an affix. It is generally described as a clitic in Old Norse (e.g. Abraham \& Leiss 2007, Faarlund 2007, Lohndal 2007), but Börjars \& Harries 2008 argues that it is an affix.
} 
The exact origin of ( $h$ )inn and bound -inn is a matter of long-standing debate in the literature. We refer to Perridon (1989:127-49) for an excellent detailed account of the facts and early views of the development. There is now general agreement that bound -inn developed from a postnominal free element, but there is still some disagreement as to the exact origin of this free element. ${ }^{11}$ We agree with Stroh-Wollin (2009:6-9) and Dahl (2010:44) in thinking that a postposed demonstrative is the more likely source, but this is not material to our analysis.

Stroh-Wollin (2009:20-21) argues that the demonstrative force of sá was weakened quite early. Convincing evidence in support of her claim is the runic inscription from Denmark in 9, which shows that sá could fulfill the same function as the definiteness marker hinn (see also Barnes 2008:84 and Harries 2015). ${ }^{12}$

$$
\begin{aligned}
& \text { (9) ... respi sten ... at Opinkor ... pan dyra ok hin drottnfasta. } \\
& \text { raised stone to Opinkor DEF valued and DEF lord.loyal } \\
& \text { '... raised the stone ... in memory of Opinkor .... the valued and loyal to } \\
& \text { his lord.' }
\end{aligned}
$$

The bound marker of definiteness survives into the modern Scandinavian languages, but is an unusual development, certainly from a European perspective; of the Germanic languages, only the Scandinavian ones have it. ${ }^{13}$ The free hinn is still in use in Faroese, Icelandic, and to some extent in Norwegian, but is lost in the other Scandinavian languages. Sá survives purely as a demonstrative in Icelandic, but in its $p$-forms as both a demonstrative and a definiteness marker with adjectives in the other languages.

From a superficial survey of data, it would seem as if the basic facts relating to definiteness marking have changed little from Old Norse to Insular Scandinavian. Definiteness can be manifest in Old Norse either as a bound marker on the noun, as in 10a, or as a syntactic element, as in $10 \mathrm{~b}$.

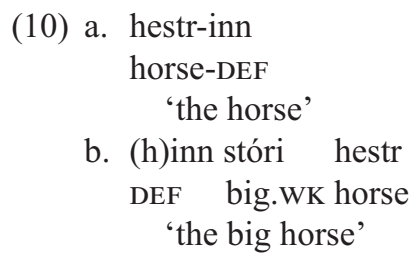

In the approach to phrase structure assumed here, however, the fact that definiteness can be overtly expressed is not sufficient to posit a category D. We argue on the basis of the optionality of marking for definiteness and the absence of complementary distribution between definiteness markers, demonstratives, and possessive pronouns that there is no unified category D in Old Norse. We also use word-order facts to argue against an articulated hierarchical structure.

These criteria are similar to those assumed by Lander and Haegeman (2013:287), though we do not take the similarity with adjectival morphology to be a strong argument (Lander and Haegeman use the criterion, but they warn that it must be used with caution (2013:293-94)). They also consider the dependence of ( $h$ )inn on the adjective

\footnotetext{
${ }^{11}$ Abraham and Leiss (2007), however, argue that the preposed free article developed from the postnominal bound one, and van Gelderen (2007:294-95) that it arose from the locative adverb hinn/hitt 'here'. StrohWollin (2009:3-6) rightly criticizes both accounts.

12 The DEF glosses are ours; Stroh-Wollin glosses the same elements as DEM, but refers to the 'pre-adjectival function' of both elements.

${ }^{13}$ Of the 620 languages referred to in Dryer 2011a, ninety-two are described as having a bound definite marker on the noun.
} 
an argument against D status. Even though we do conclude that (h)inn in Old Norse is not a $\mathrm{D}$, its dependence on the adjective does not per se preclude $\mathrm{D}$ status. The modern equivalent in all Scandinavian languages but Icelandic is also dependent on the adjective, but the discussion by Lander and Haegeman (2013) makes clear that they would consider modern Scandinavian languages to be DP languages and hence presumably the equivalent element in modern Scandinavian to occur in D. In his discussion of the emergence of a D element in Dutch, Van de Velde (2010:268-69) also assumes obligatoriness and complementary distribution as criteria. He further assumes that if a language can be shown to have dedicated definiteness elements (articles), then a D should be posited. This criterion is more difficult to apply for morphologically bound elements such as -inn, unless the noun is assumed to occur in $\mathrm{D}$, but to us that requires a different type of evidence, as we shall see in $\S 6.3$. Van de Velde adds a criterion relating to word order and one that excludes elements that can occur as predicates.

Old Norse differs crucially from modern Scandinavian languages in that noun phrases need not contain any explicit marker of definiteness in order to receive a definite interpretation. The same holds for indefiniteness. Noun phrases such as those in 11 receive an unambiguous definite and indefinite interpretation, respectively, even though there is no exponent of (in)definiteness. In an interesting study, Leiss $(2000,2007)$ argues that there is a clear pattern to the presence or absence of marking; definiteness is not marked explicitly when the noun phrase is a theme (rather than a rheme) and hence understood to be definite. Harries (2015:33-34) finds indirect supportive evidence in that noun phrases with a definite interpretation in subject function are more often unmarked than those functioning as objects. However, she also argues that Leiss's hypothesis would require some modification in order to account for the use of free $(h)$ inn with adjectives (2015:40-41).

(11) a. Austmaðr kvezk ...

east.man said

'The Norwegian said ...'

(Gunnl 2.29)

b. Ok gekk kona fyrir útibúrsdyrrin

and went woman in.front.of outhouse.door.DEF

'A woman went in front of the door of the outbuilding'

Furthermore, definiteness markers are not in complementary distribution with each other, nor with demonstratives or possessive pronouns. We provide some examples of the range of variation in 12 (see also Barnes 2008:84-86 and Lander \& Haegeman 2013: 311-12).

(12) a
petta sverð
DEM sword
'this sword'
b. sá Qrninn
DEM eagle.DEF
'that eagle'
c. inu syðra landinu
DEF southern.WK land.DEF
'the southern land'
d. pessi inn underligi hlutr
DEM DEF wonderful.wK thing
'this wonderful thing'

(Hró 3.139)

(Gunnl 2.39)

(Lax 5.17)

(ER 6.53) 
e. pessi pinni meðferð

DEM 2sG.POSS cooperation

'your cooperation'

(VG 5.30)

f. in góðu klædi pin

DEF good.WK clothes 2sG.POSs

'your good clothes'

g. pitt hitt milda andlit

2sG.POSS DEF mild.wK face

'your mild face'

h. draumkonan sú hin verri

dream.woman.DEF DEM DEF worse.WK

'the dream woman who was worse' (Gísla saga Súrssonar 33; Dahl 2004:150)

i. umskaða pann inn mikla ok inn illa

harm DEM DEF big.WK and DEF bad.WK

'that big and bad harm'

(BN 49.68)

As these examples illustrate, not only is there flexibility with respect to cooccurrence, but the order between the elements is also not firm, with the exception that the definiteness marker ( $h$ )inn only occurs with a weak adjective and then always immediately preceding it. We return to these issues in $\S 4.3$ and $\S 4.4$.

Though there are examples of so-called DOUBLE DEFINITENESS - that is, the cooccurrence of a syntactic definiteness marker with a noun marked for definiteness, which is to become a characteristic feature of Faroese, Norwegian, and Swedish - it is actually relatively uncommon, so it is not easy to find examples such as $12 \mathrm{~b}, 12 \mathrm{c}$, or $12 \mathrm{~h}$. Barnes (2008:84) states that double definiteness is uncommon in Old Norse, but that a combination of the bound article and some syntactic definiteness marker is more common in Norwegian sources than in Icelandic ones. ${ }^{14}$

The modern Scandinavian indefinite determiner en developed from the numeral einn 'one'. It is generally recognized that in Old Norse the element did not have the distribution of an indefinite determiner, but still functioned as a numeral at this stage, or had meanings such as 'only', 'a single', 'a certain', or 'sole' (see, for example, Heusler 1921: 131, Wessén 1992:47-48, Faarlund 2004:56, and Skrzypek 2010:155-93).

4.3. Adjectival inflection. Adjectives in Old Norse carried marking for a feature traditionally referred to as weak/strong, which was closely associated with definiteness, as illustrated in 13 (cf. Wessén 1992:42).

(13) a. blindr er betri, en brendr séi

blind.STR is better than burnt.STR is

'a blind man is better than a burnt man'

(Háv 71.4)

b. Svo segir Bragi skáld gamli. such says Bragi poet ancient.wK

'So says Bragi, the ancient poet.'

(Gylf 7.11)

${ }^{14}$ We take double definiteness to be an empirical fact of modern Faroese, Norwegian, and Swedish, but note that Rießler (2011:164) argues that the elements we refer to as syntactic definiteness markers in these languages do not give rise to double definiteness because they are not actually definiteness markers, since their presence or absence 'is determined by the availability of an adjective and not the referential status of the noun phrase'. The classic reference on double definiteness in the Scandinavian languages is Lundeby 1965. Plank (2003) provides a typological overview of the phenomenon. Julien (2005) argues that the two definiteness markers contribute different aspects of definiteness in modern Scandinavian. 
However, the [WEAK/STRONG] distinction is not quite the same as the [DEF \pm ] marked on determiners and nouns; the weak form aligns with definiteness, but the strong form can also be found in noun phrases with definite reference (see Delsing 1994, Faarlund 2004:86, and Stroh-Wollin \& Simke 2014:102-3 for examples and discussion).

A weak adjective is almost always immediately preceded by (h)inn, though in some cases the demonstrative sá can occur instead, as illustrated in 9 above. This is regardless of whether the adjective modifies a noun, as in $12 \mathrm{c}, 12 \mathrm{~d}$, and $12 \mathrm{f}-\mathrm{i}$, or whether the adjective functions as the head of a noun phrase, as in 14 .

(14) fyrir pá sok, at hinir snauðu áttu litlar jarðir, en hinir auðgu for DEM reason COMP DEF poor.WK have little earth and DEF rich.WK hugðust mundu leysa sín óðul pegar er peir vildu think must redeem their udal at.once REL they want 'because the poor had little land, and the rich believed that they would be able to redeem their udal rights as soon as they wanted'

(Har 32.30-32)

The association between definiteness markers and adjective phrases is consistent with developments in a number of languages. Generally, if there are dedicated definiteness markers in a language, there will be as many or more of them in a noun phrase that includes adjectival modification (see Renzi 1992 for Romance, Harris 1980 for Slavonic, and Rießler 2011 for typological data). We return to the role of (h)inn in $\S 4.5$.

4.4. WORD ORDER. Turning to word order now, the order within the noun phrase in Old Norse is generally described as relatively free; demonstratives, adjectives, and possessives can appear either before or after the noun. In fact, Faarlund (2004:55) goes as far as to say that 'the word order within the NP seems almost totally unconstrained by syntactic rules'. However, as Faarlund himself goes on to show, there are patterns to the distribution between pre- and postnominal position, so that some constraints can be identified. Still, as will become apparent, we are inclined to agree with Faarlund's statement insofar as the constraints on ordering are not SYNTACTIC in nature.

It is generally argued in the literature that the unmarked order involves adjectives, possessive pronouns, and possessive noun phrases following the noun, as illustrated in 15 for adjectives and in 16 for possessors (see for instance Valfells \& Cathey 1981, Faarlund 2004:68-69, and Harries 2015:\$3.3). ${ }^{15}$

(15) a. hann hafði sét konu fagra

he had seen woman beautiful.sTR

'he had seen a beautiful woman'

b. Jófriðr fœddi meðan meybarn ákafa fagrt

(Sno Edd 1.69)

J. give.birth meanwhile girl.child greatly beautiful.sTR

'meanwhile Jófriðr gave birth to a very beautiful baby girl'

(Gunnl 3.12-3)

(16) a. hest min skaltu taka

horse 1sG.POss shall.you take

'you shall take my horse'

b. Pá lét Njorðr kalla til sín Skírni, skósvein Freys

then let N. call to REFL S. servant Frey.GEN

'Then Njördr summoned Skírni, Frey's servant'

(Gunnl 3.14-5)

(Sno Edd 1.63)

\footnotetext{
15 Though we continue to refer separately to possessive pronouns and adjectives, we concur with the conclusion drawn by Heltoft (2010:20) that possessive pronouns and adjectives actually formed one category at this stage. Barnes (2008) also uses the term 'possessive adjective'.
} 


\section{c. Ok er paðan komit kyn allra Orkneyinga jarla}

and are from.that come kin all.GEN Orkney.GEN earls.GEN

'And from this came the kin of all Orkney's earls'

When referring to factors that may cause an adjective to occur in prenominal position, these authors use terms such as 'emphatic', 'focused', or 'prominent' - that is, they can be described as information-structurally marked.

It is appropriate at this point to briefly consider the form and position of adjectives in a broader perspective. There is a long tradition of work, within both traditional grammar and formal semantics, of distinguishing between adjectives that function to delimit or restrict the reference of the accompanying noun-in the terminology of Bolinger (1967), 'referent-modifying' - and those that combine with and modify the predicate expressed by the noun - a function that Bolinger dubs 'reference-modifying' (for other labels for the same contrast, see the summary in Vincent 2007:58). The standard example is old friend, which may mean 'a friend of advanced years' (referent modifying) or 'a friend of long standing' (reference modifying). ${ }^{16}$ At the same time there is good evidence elsewhere within Indo-European that this semantic distinction maps onto word order, with postnominal position being preferred for the adjective in its referentmodifying uses, while prenominal position is associated with reference-modifying uses (for Greek, see Dik 2007 and Bakker 2009, and for Latin see Devine \& Stephens 2006:Ch. 5 and references there). Thus, compare Italian un amico vecchio, with N-A order, 'a friend who is old' and un vecchio amico, with A-N order, 'someone who has been a friend for a long time'. Indeed, in this prenominal position the adjective has sometimes been analyzed as forming a compound with the noun (Radatz 2001); see also the analysis of prenominal adjectives in English by Sadler and Arnold (1994).

Within languages that exploit the positional difference in this way, it is the prenominal adjectives that are associated with emphasis and emotive overtones. By contrast, it is interesting in this context to note that for Old English, the prenominal position is generally described as being the unmarked one (e.g. by Mitchell (1985:78) and Fischer and colleagues (2000:46)). A search of texts up to 1350 in IcePaHC (Wallenberg et al. 2011) indicates that in this selection of Old Norse texts, the adjective does in fact more frequently precede the noun and hence would appear also to go against the generalization. However, a more systematic study of a broad range of texts is required to understand better the conclusions drawn for Old Norse by authors such as Valfells and Cathey (1981), Faarlund (2004), and Harries (2015).

It is clear that structural factors also play a role in the placement of adjectives. For instance, Old Norse strongly avoids more than one adjective preceding the noun, so when there is more than one adjective modifying a noun, it is common for one to occur prenominally and the other coordinated following the noun, as in $17 \mathrm{a} .{ }^{17}$ When an adjective is followed by a complement, it also standardly follows the noun, as in $17 \mathrm{~b}$.

(17) a. mikit hús ok fagrt

big.STR house and beautiful.sTR

'a big and beautiful house'

(Sno Edd 1.56)

\footnotetext{
${ }^{16}$ This distinction interacts in interesting ways with notions such as restrictive vs. nonrestrictive and intersective vs. nonintersective, but this is not the place to go into these distinctions in detail.

${ }^{17}$ Under the right information-structural conditions, an adjective can even be extracted from its noun phrase and fronted to clause-initial position; for further data and analysis, see Platzack 2008.
} 
b. maður göfuglegur yfirlits og með sæmilegum

man noble.M.SG.NOM appearance.GEN and with becoming.M.SG.DAT búningi

attire

'a man of noble appearance and with becoming attire'

(IcePaHC 1210.THORLAKUR.REL-SAG, .83)

There is then some variation within the noun phrase driven by a range of factors. However, we concur with the authors cited above that beyond this general flexibility there is also an information-structurally marked initial position. This is best illustrated using possessive pronouns.

The examples in 18 and 19 come from Gunnlaugs saga Ormstungu, a text with plenty of examples of postnominal possessive pronouns also involving kinship terms: faðir hans 'his father' (Ch. 1), húsfreya pin 'your wife' (Ch. 2), dóttur pinnar 'your daughter' (Ch. 2), bróður sinn 'his.ReFL brother' (Ch. 3), kona hans 'his wife' (Ch. 5), froendi minn 'my kinsman' (Ch. 5), and many more. In 18 and 19, the possessor precedes the noun, and in all cases there is contrastive emphasis. In 18 there is explicit contrast between the two fathers, whereas the examples in 19 come from a discussion about whose daughter Helga actually is and hence potential fathers are contrasted. ${ }^{18}$

(18) at minn faðir væri eptirbát pins fǫour

COMP 1sG.POSS father was after.boat 2sG.POSS.GEN father.GEN 'that my father trailed in the wake of yours'

(19) a. pvi at hon er eigi hans dóttir ... COMP she is not 3sG.M.POss daughter

b. en pó sé hon pí dóttir ...

but if is she 2sG.POss daughter

c. pá er pessi pín dóttir en eigi mín

then is this 2sG.POss daughter and not mine

'(She has not got the good looks of Oláf the Peacock) because she is not his daughter ... but if she is your (Thorgerd's) daughter ... this is your (Thorstein's) daughter, not mine (Thorgerd's).' (Gunnl 3:43-46)

The idea that the prenominal position marks a special information status also in Runic Old Norse is made explicit by Antonsen (1975:24-25), who describes the order in prijōz dohtriz 'three daughters' as being unexpected in the Northwest Germanic Runic language and states that the quantifier 'probably is topicalised in view of the order in other varieties'.

The freedom of word order we have seen so far holds also for demonstratives; they can occur before or after the noun, as illustrated in 20 and 21.

(20) a. Hversu lízk pér á mey bessa?

how likes you about girl DEM

'What do you think of this girl?'

(BN 1.34)

\footnotetext{
${ }^{18}$ It should be pointed out that one of the two remaining vellum manuscripts of this text has postnominal possessors in 18 (Foote 1957:22). This does not affect our generalization, however, since all we are claiming is that when elements are prenominal, it is because they have some special information status.
} 
b. Af horni pessu pykkir pá vel drukkit ef i einum drykk gengr of horn DEM be.thought it well drunk if in one drink go af out.of

'It is thought that drinking from this horn is done well if it is emptied in one drink'

(Sno Edd 1.275)

(21) a. ok til pess húss gekk kona

and to DEM house went woman

'and to this house the woman went'

(Sno Edd 1.56)

b. Hann festir petta mál

he settles DEM matter

'He settles this arrangement'

(22) a. at hann kvað at Legbergi kviðling penna ...

COMP he recited at L. short.verse DEM

'that he recited at Logberg this short verse: ... ' (verse follows)

(Lib Is1 4.81)

b. pa drakk hann ok kvað visu pessa ...

then drank he and recited verse DEM

'then he drank and recited this verse: ...' (verse follows) (Porf 5.307)

The use of the demonstrative in 20 is deictic, and it occurs postnominally. In 21 , the demonstrative is used anaphorically, referring to something that has just been mentioned in the context, and it is prenominal. In 22 , it refers to something that is about to come in the text, so can be described as cataphoric, and it follows the noun. There may then be some correspondence between the function of the demonstrative and its position, but this is no more than a tendency (see Harries 2015:83-88 for more details on the position of the demonstrative).

4.5. AnAlysis. On the basis of the data examined so far, we can draw a number of initial conclusions. Old Norse does not have a dedicated definite element, either free or bound, in the sense that there is no element that is obligatory for a noun phrase to receive a definite or indefinite interpretation. There is no category $\mathrm{D}$ at the level of the noun phrase in Old Norse as there is no evidence of definite elements competing for one position. Since there is no category D, there is no functional DP projection. Our conclusions are in line with those of Lander and Haegeman (2013), though we reach them via a somewhat different line of reasoning. Lander and Haegeman conclude that the syntactic definiteness markers are closest to adjectives in category and behave like 'lexical items adjoined to NP as "adjuncts" ' $(2013: 296)$ (though they do make explicit that it is not their intention to provide a formal analysis of NP and DP structures). We conclude instead that the AP is the actual structural locus for definiteness marking. Our conclusions are closer to those of Heltoft (2010:14), who states that 'definiteness is a paradigmatic contrast in adjectives and thus in NPs, but not in nouns'. Our conclusions are consistent with discussion of the connection between definiteness markers and adjectival modification in other varieties of early Germanic by earlier authors, for instance Curme (1910) and Heinrichs (1954).

They are also in line with more recent work; Perridon and Sleeman (2011:8) argue that 'North-Germanic and Rumanian developed an "adjectival" article, which in principle only has scope over an adjective', and Stroh-Wollin (2009:7) states that (h)inn 'seems to be just a formal element preceding adjectives with the so-called weak inflection'. Rießler (2011:164) essentially analyzes (h)inn as an element that allows the weak adjective to have a nominal function. However, in spite of this general perception of 
(h)inn-A as a unit, no formal analysis of Old Norse that we are aware of captures this. Instead, (h)inn occurs as the head of the noun phrase at some level (e.g. Faarlund 2004:57 or Stroh-Wollin 2009:19). We propose an analysis in which (h)inn and the adjective phrase form a constituent. It is interesting to compare this with the analysis proposed by Leu (2008) for modern Scandinavian languages as well as English. We return to a discussion of this in $\S 6.3$.

Though this level of detail is not relevant to our formal analysis, there is a further issue of whether it is the adjective or (h)inn, or possibly both, that contributes the definiteness feature associated with weak adjectives. Ratkus (2010:249) argues for Gothic and early Germanic in general that the definiteness resides in the $-n$ ending of the weak adjective, not in the syntactic marker. Similarly, Stroh-Wollin (2009:5) argues that "the original function of the pre-adjectival article was not to convey "definiteness" to the noun phrase'. This in turn is consistent with Rießler's (2011) analysis of the role of (h)inn being essentially structural, as a nominalizer.

We conclude that, syntactically, the word order is to a large extent free; the patterns we see in the order are driven by a number of factors, some structural and some semantic, but also some information-structural in nature. The relatively free word order suggests to us some degree of nonconfigurationality, which is best represented as a flat structure in which elements are not associated with particular structural positions. We assume that configurationality is not an either/or property of natural languages, but that different constituents within a single language may exhibit this property to differing degrees. We do, for instance, recognize an AP within the generally nonconfigurational noun phrase. There has been some debate about configurationality in relation to Old Norse, with Faarlund (1990) arguing that Old Norse was a nonconfigurational language and Braunmüller (1994) making the case for Old Norse noun phrases being nonconfigurational. By contrast, Platzack (1991), Stockwell and King (1993), and Rögnvaldsson (1995) all argue against the conclusions drawn by Faarlund (1990). However, they do so on the basis of a broader notion of nonconfigurationality than order and constituency alone. Within a parallel correspondence architecture such as LFG, word order and constituency of the noun phrase itself are the sole determining factors.

In addition to the flexibility associated with the nonconfigurationality, there is an initial position that is associated with information-prominent and contrastive elements. This supports an analysis in which the noun phrase contains a structurally defined, dedicated, discourse-prominent position on the left edge. The conclusions we have drawn give us the tree in 23 for the Old Norse noun phrase.

(23) Old Norse noun phrase c-structure

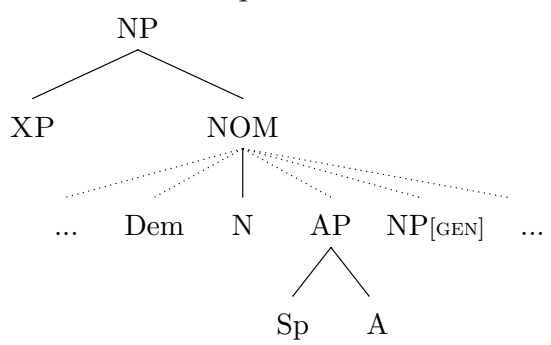

This tree has an information-structurally privileged position on the left edge where adjectives and possessors are assumed to be positioned when they are emphasized. ${ }^{19}$

\footnotetext{
${ }^{19}$ For a summary of work on information structure within the noun phrase, see Aboh et al. 2010. Scholars who have suggested an information-structurally motivated position within the noun phrase, such as Giusti
} 
The free word order is captured by means of a flat structure under NOM, avoiding the traditional $\mathrm{N}^{\prime}$ since its association with recursion would be inappropriate here. The daughters of NOM could also include elements such as PPs and relative clauses. The order of the elements under NOM is not fixed and is likely to be influenced by factors such as weight and scope and also stylistic considerations. We interpret the data as evidence that definiteness was associated with the adjective at this stage, and in the tree the node hosting $(h)$ inn is found within the AP. Since we have concluded that there was no category D at this stage, we represent it here as $\mathrm{Sp}$ (ecifier); its role is not to determine reference, but to change the function of a weak adjective. In indefinite noun phrases, there was no separate element present, only the strong feature on the adjective.

Turning now to the mapping to f-structure, the XP daughter of the NP is a grammaticalized discourse function (see definition in $\S 2$ ); hence it is linked to a discourse function by virtue of its unique position. We have used INF-PRIV for information-structurally privileged here rather than a more specific term such as Focus since we have not explored in detail the exact nature of the factors that motivate initial positioning. The elements under NOM, by contrast, receive their functions by virtue of their categorial status and their features, not their position. So, an NP[GEN] is a possessor regardless of where under the NOM it occurs, and similarly for the AP. A modifier such as an AP has the function adjunct, and since modifiers can occur recursively, its value is a set of f-structures. Hence the equation under AP involves a set value. The $\uparrow=\downarrow$ annotations indicate that these elements share their f-structure with that of NOM, which in turn shares them with the NP. This means that they are co-heads in the sense that they all contribute features and values to the same f-structure, that of the NP as a whole. The resulting annotated tree is provided in 24 .

(24) Old Norse noun phrase c-structure with mappings to f-structure

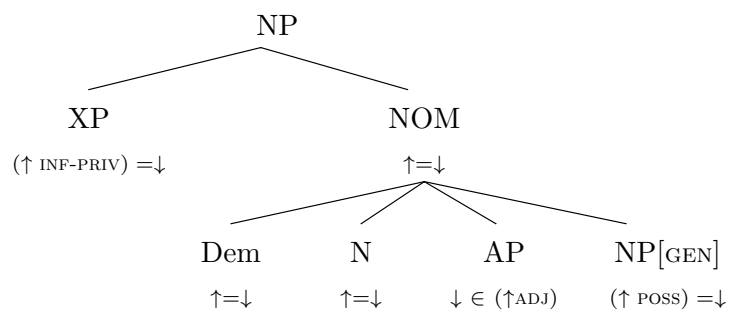

5. EARLY FAROESE. There is a wealth of material in different genres for the earliest predecessor of Faroese - Old Norse - and similarly for modern Faroese. However, there is less material available from the period in between. This means that whereas there are numerous analyses of the development of (aspects of) the noun phrase in other Scandinavian languages, less has been written about Faroese. Though our general point about noun phrase structure developing over time applies to the Scandinavian languages in general, we focus on Faroese in spite of the scarcity of data, exactly in order to broaden the data set considered in the discussion of Scandinavian noun phrases. As we shall see, the fact that Faroese developed from the same origins as Norwegian - a double definiteness language - but was later under strong influence from Danish—not a double definiteness language - for an extended time period also makes it an interesting case study. We look at two stages of Faroese, first the language of Seyðabrcevið 'The sheep charter', from 1298, the oldest remaining document in Faroese, and second the language of the period that can be referred to as the revival period through Føringatidini, from the 1890s.

(1996), Bernstein (2001), or Haegeman (2004), have done so within a very different approach to syntactic structure from that taken here. 
For an overview of the history of Faroese, we refer to Thráinsson et al. 2004, and for further data from these periods to Harries 2015:Ch. 4.

5.1. The language of SEYĐABREVIĐ. Unlike another early document, Føroyingasøgu 'The Faroe sagas', Seyðabrcevið was written in the Faroe Islands and hence is likely to provide the most accurate picture of the Faroese language at the time. The document is only around 3,000 words long and it is written in the language typical of statutes, with more frequent general reference such as 'if any man ... ' rather than specific or definite reference, which influences the number of definite noun phrases one can expect. Nonetheless, we are able to see the beginnings of some changes compared to Old Norse.

In Seyðabravið, unmodified nouns must occur in their definite form, as in $25 \mathrm{a}$, in order to get a definite interpretation; the only exception to this is when they are complements of prepositions. Indefinite noun phrases, by contrast, can consist of just a noun, as in $25 \mathrm{~b}$. There is then evidence that definiteness needs to be marked explicitly, unlike in Old Norse, but that an indefinite determiner has still not developed.

(25) a. Bardr Peterson war ritade brefet.

B.P. was written letter.DEF

'Barður Peterson had written the letter.'

b. Ef sauðr gengi $\mathrm{j}$ annars haga ...

if sheep goes in other's field

'If a sheep goes into another man's field ...'

The only examples we can find in Seyðabrcevið of the syntactic definiteness marker hinn are in combination with a numeral and preceding a superlative adjective, that is, where the nominal already has unique reference. ${ }^{20}$

(26) a. hin iij fimt

DEF three period

'the third period'

b. hin kærazste vin

DEF dearest friend

'the dearest friend'

In Seyðabrcevið, the demonstrative precedes the noun, as illustrated in 27. At this stage the syntactic markers of definiteness and possessive pronouns occur in complementary distribution, and there is no evidence of double definiteness; demonstratives and hinn do not cooccur with definite nouns.

(27) $\mathrm{Nu}$ gengr bessi saiðr aptr i pann haga now goes DEM sheep after in DEM pen

'Now this sheep goes back in that pen.'

At this stage, adjectives tend to be prenominal, as in $28 \mathrm{a}$, but they may still be postnominal, as in $28 \mathrm{~b}$.

(28) a. gamlan saið old.STR sheep

'an old sheep'

${ }^{20}$ Dahl (2010:124), with reference to Thompson (1988), points out that definite noun phrases with modification are generally rare, and given the scarcity of data for this stage of Faroese, firm conclusions cannot be drawn with respect to the interaction between definiteness markers and modifiers. It is interesting to note that the environments in 25 are ones where in Present-Day Faroese a syntactic definiteness marker is not required; see Harries 2015:174-75. 


$$
\begin{aligned}
& \text { b. ii vitni skilrik } \\
& \text { two witnesses trustworthy.sTR } \\
& \text { 'two trustworthy witnesses' }
\end{aligned}
$$

The possessive construction appears similar to that of Old Norse at this stage of the language; the possessor generally follows the possessum, as in the examples in 29, but when used contrastively, as in 30 , it can be fronted.

(29) a. fænad hans

livestock 3sG.M.POSS

'his livestock'

b. haglendi annarz manz

outfield other.GEN man.GEN

'another man's outfields'

(30) Pa skal han fa til ii vitni skilrik at pat er hans

then shall he get to two witnesses trustworthy COMP DEM is 3sG.M.POsS

sauðr.

sheep

'Then he shall provide two trustworthy witnesses to confirm that it is his sheep (rather than someone else's).'

At this early stage, keeping in mind the limitation of the data set, word order appears still to be relatively free, and there is some evidence of an initial privileged position, given the distribution of possessive pronouns illustrated in 30. Though there is still no dedicated indefiniteness marker, marking for definiteness appears to be obligatorythough it can be marked either syntactically or morphologically on the noun-and the different definiteness markers occur in complementary distribution. The fact that syntactic markers of definiteness do not cooccur we take as evidence that a D category has developed, of which hinn and the demonstrative are members. There is, however, no evidence at this point that it is associated with a particular structural position, and hence we do not associate the D with a DP projection. We can then assume a schematic structure such as 31 for this stage of the language.

(31) Noun phrase c-structure in the language of Seyðabrcevið

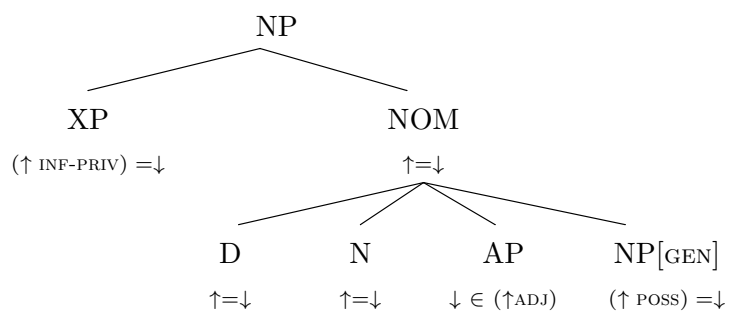

Both $\mathrm{N}$ and $\mathrm{D}$ are associated with $\uparrow=\downarrow$, and hence a feature [DEF +$]$ will become part of the noun phrase regardless of where it finds exponence. As we showed in $\S 2$, the LFG formalism allows features to be contributed by either a syntactic or a morphological element.

5.2. The LANGUAgE OF FØRINGATÍIINDI. We turn now to the language of the newspaper Føringatíðindi, dating from 1890s. ${ }^{21}$ This is of particular interest to us since it was published at a time of increased interest in the Faroese language. Indeed, the front page

\footnotetext{
${ }^{21}$ The references for the examples are to FT (Føringatiðindi) Volume.Number.Page, which can be found at http://timarit.is.
} 
of the first issue of the newspaper is dedicated to a discussion of the Faroese language, with contrasting references to Icelandic and Danish, and in subsequent issues, there is frequent reference to the role of Faroese and the (negative) influence of Danish. The language of this publication is then the result of a conscious effort to use a specifically Faroese language.

In a development from the time of Seyðabrcevið, marking for indefiniteness is now also required, as in 32 , so that an unmodified noun will occur either in its definite form or with the indefinite article.

$$
\begin{aligned}
\text { (32) a. eitt blað } \\
\text { INDF newspaper } \\
\text { b. ein vælkomin gestur } \\
\text { INDF welcome.sTR guest }
\end{aligned}
$$

Hinn is used as a definiteness marker, but in competition with tann, which developed from a form of the demonstrative sá. Indeed, the two examples in 33 are from the same article, and there is no obvious difference with respect to how the noun phrase is used.

(33) a. hin gamli skiparin

$$
\text { DEF old.WK skipper.DEF }
$$

b. tann gamli skiparin

DEF old.WK skipper.DEF

'the old skipper'

As in the earlier stage, demonstratives do not cooccur with the syntactic definiteness marker or with possessive pronouns. When a demonstrative combines with an unmodified noun, the noun most frequently occurs in its definite form, as in 34, but it can also combine with the unmarked form, as in 35 .

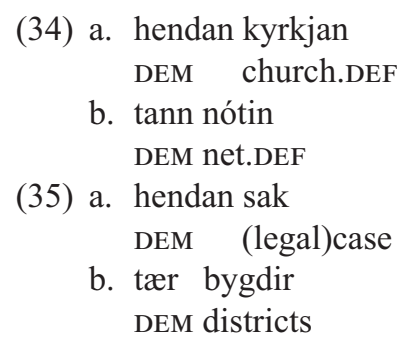

When the noun is premodified, the modifier is generally preceded by a syntactic determiner, though examples such as 36 can be found. As with unmodified nouns, double definiteness, as illustrated by 37, appears more common. However, examples such as those in 38 can also be found. At this stage Faroese has then not developed obligatory double definiteness.
(36) a. nýggji blaðstýrarín new.WK newspaper.editor.DEF 'the new newspaper editor'
b. störstu skyldina biggest.wK blame.DEF 'the biggest blame'
(37) a. hesar ungu landsmenninar DEM young.WK countryman.PL.DEF 'the young countrymen'
b. hin viðgitni Danski fólkatingsmaðurin DEF famous.wK Danish.wK member.of.parliament.DEF 'the famous Danish member of parliament'


(38) a. hesu stuttu ferð

DEM short.WK trip

(FT 1.1.3)

b. hendan stranga æðulóg

DEM strict.wK eider.law

(FT 1.8.2)

It is interesting to note that single definiteness is particularly common at this stage when the noun is followed by a relative clause, as in $39 \mathrm{a}-\mathrm{a}$ construction that still exists in modern Swedish, as illustrated in $39 \mathrm{~b}$, even though the same combination without the relative clause is ungrammatical, as 39c shows. However, according to Julien (2005: 78), with reference to Zakaris Hansen (p.c.), the construction sounds 'unnatural' in modern Faroese.

(39) a. tey nýggju Vaskíevnir, sum í seinri tíðini eru uppfunnin DEF new.WK cleaning.agents REL in later time.DEF are invented (FT 1.3.3)

b. de nya rengöringsmedel som uppfunnits på den senaste tiden DEF new.WK cleaning.agents REL invent.PASS on DEF latest time.DEF

'the new cleaning agents which have been invented in recent times'

c. De nya *rengöringsmedel/rengöringsmedlen fungerar bra.

DEF new.WK cleaning.agents/cleaning.agents.DEF work well

Possessors can occur prenominally without any specific information status being implied, as illustrated in 40, where the context makes clear that no contrast is implied. Particularly when the noun phrase contains an adjective phrase, the prenominal position is the most common position for possessors, as in 41 .

(40) a. Tað var tí ikki sjáldsamt at teir sendu síni börn

it was therefore not unusual that they sent 3PL.POSS.REFL children burtur til vitugt fólk at fostra upp. away to wise people INF bring up

'It was therefore not unusual that they sent their children to be raised by wise people.'

(FT 1.2.1)

b. tað hvatt ikki Föroyskt av hennara munni fjúrtan dagar eftir at there become not Faroese of 3sG.F.POSs mouth fourteen days after INF hon var heim komin. she was home come

'no Faroese had come out of her mouth during the first fourteen days after her return'

(FT 1.1.3)

(41) a. Chr. Christiansens nykeypta skip er nú komið til Havnar

Chr. Christiansen.GEN newly.bought ship is now come to harbor í ollum góðum.

in all good

'Chr. Christiansen's newly bought ship has now arrived in the harbor safe and sound.'

b. folkið hevurlov til at velja av sínum bestu

people.DEF have permission to INF choose of 3PL.POSS.REFL best

monnum til at sita $\mathrm{i}$ lögtinginum

men to INF sit in parliament.DEF

'the people may choose from among their best men those who will sit in the parliament'

(FT 1.2.2)

Though examples of nonpronominal possessors in genitive case can be found, as illustrated by 41a, it should be pointed out that a decline in the use of the genitive case can be seen at this stage, with a prepositional possessor being used instead. Such prepositional possessors occur postnominally. 
The language of the 1890 s, as represented in Føringatioindi, is, as we shall see, very similar to modern Faroese. There is now minimal flexibility in word order and no evidence of an information-structurally privileged position. An indefinite article has developed and tann is starting to show the distribution of a definite article, though it remains also as a demonstrative. There is a tendency for the initial element of the noun phrase to be one that carries marking for definiteness, including weak adjectival marking as in 36. A clear difference is that at this stage, there is not yet a firm pattern with respect to double definiteness, but both single and double marking exist. Because of the similarities with Present-Day Faroese, we do not provide an analysis here, but refer to the analysis in $\S 6.3$.

\section{Present-Day faroese.}

6.1. (IN)DEFINITENESS MARKERs. Present-Day Faroese (PDF) retains the bound definiteness marker, and the nondemonstrative use of tann has expanded, so that it is now the most frequent syntactic definiteness marker. ${ }^{22}$ Hinn is still used as a definiteness marker, though frequently associated with a literary or archaic style. It is more commonly used to mean 'the other'. As in the earlier stage of Faroese, adjectives precede the noun, but in a development from the 1890 s, a syntactic definiteness marker is generally required when there is premodification.

(42) a. teldan

computer.DEF

'the computer'

b. tann stóra gatan

DEF big.WK mystery.DEF

'the/that big mystery'

c. hin størsta vindmylluparkin í Europa

DEF biggest windmill.park.DEF in Europe

'the biggest wind farm in Europe'

As $42 \mathrm{~b}$ and $42 \mathrm{c}$ show, the syntactic definiteness marker cooccurs with the morphological marker on the noun. This is the case also with demonstratives, as in 43. As in the earlier stages, however, the syntactic definite elements cannot cooccur.

(43) a. tann bilin

DEM car.DEF

'that car'

b. hetta gamla orðið

DEM old.WK word.DEF

'this old word'

The data in 42 and 43 lead to the conclusion that Faroese displays double definiteness: a syntactic definite marker has to cooccur with a noun carrying the bound definite marker. Double definiteness divides the modern Scandinavian languages: Swedish and Norwegian have double definiteness, whereas Danish and Icelandic do not. ${ }^{23}$ With respect to Faroese, however, slightly different views on this issue are represented in the literature;

\footnotetext{
22 In this section, we use 'Faroese' to refer to PDF. All examples are taken from, or in a few instances adapted from, Färöisk textsamling, which is available at Språkbanken (http://spraakbanken.gu.se/), or from a corpus of Faroese prose and newspaper texts constructed for Harries 2015. We are grateful to those who have been involved in making the texts in the electronic corpus publicly available.

${ }^{23}$ As pointed out by a referee, Icelandic has limited double definiteness, in particular in constructions with hinn meaning 'the other'.
} 
Thráinsson and colleagues (2004) and Julien (2005) class it with the Mainland Scandinavian languages as having double definiteness, whereas Lockwood (1977) and Barnes and Weyhe (1994) describe double definiteness as a tendency only. It is indeed possible in Faroese to have a prenominal adjective without an accompanying syntactic definiteness marker, as in 44. But as Harries (2015:\$4.4) shows, the syntactic determiner can be omitted only in a constrained set of environments, for instance with unique descriptions, where the modifier gives the noun phrase a unique reference, or in nonreferential noun phrases. These contexts tend to permit single definiteness in Norwegian and Swedish also and require separate analysis (see for instance Julien 2005:30-33).

(44) a. meðan svarti deyðin herjar í 1348

while black.wK death.DEF ravishes in 1348

'while the Black Death ravishes in 1348'
b. hægsta fjallix í Fóroyum
highest.wK mountain.DEF in Faroe.Islands
'the highest mountain in the Faroe Islands'

As in the Mainland Scandinavian languages, it is not modification in general that triggers the requirement for a syntactic determiner, only premodification. As the examples in 45 show, a definite noun can combine with postmodification to form a referential noun phrase.

(45) a. borðinum, sum høvuðspersónarnir skuldu sita við

table.DEF REL head.persons.DEF would sit at

'the table that the main people would sit at'

b. maðurin í bilinum

man.DEF in car.DEF

'the man in the car'

As in the earlier stage, explicit syntactic marking is required for indefinite noun phrases also, as in 46. As indicated in Lockwood 1977:109 and Thráinsson et al. 2004: 91, some indefinite noun phrases may occur without the indefinite article, but this is in similar contexts to those where the definite article can be omitted, and we assume here that the article is obligatory in indefinite referential noun phrases.

(46) a. *(Ein) ungur maður hevði blandað methanol í brennivín, og INDF young.STR man had mixed methanol in schnapps and síðan selt tað til *(ein) handilsmann.

then sold it to a tradesman

'A young man had mixed methanol in schnapps and then sold it to a tradesman.'

b. *(Eitt) nýtt dagtilhald er latið upp í høvuðsstaðnum. INDF new.STR.N day.residence is let up in capital.DEF

'A new day center was opened in the capital.'

From the data presented so far in this section, we can conclude that referential noun phrases require explicit marking for definiteness and indefiniteness. Furthermore, the definiteness is associated with the left edge of the noun phrase, and the weak/strong marking on the adjective cannot satisfy this requirement; when the definite noun is preceded by an adjective, a syntactic definiteness marker needs to be present for the noun phrase to be referential.

6.2. WORD ORDER. Adjectives are always prenominal (except when themselves postmodified), but there is still some variation in possessor-possessum order when the possessum is unmodified. When there is adjectival modification, however, the preferred 
order is with the possessor preceding the noun and the adjective, so that the order in $47 \mathrm{a}$ is overwhelmingly more common than that in $47 \mathrm{~b} .{ }^{24}$
(47) a. mín góði vinur
1sG.POSS good.wK friend
b. góði vinur mín
good.wK friend 1sG.POSs
'my good friend'

When there is no modification, there is a trend attested in Faroese toward a preference for a definite marked noun if the possessive follows the noun; whereas $48 \mathrm{a}$ is the traditional form, $48 \mathrm{~b}$ is gaining ground.

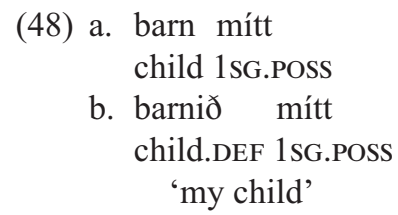

The distribution of possessive determiners, which give a definite reading, provides further evidence for the generalization that definiteness is associated with the left edge, and that the adjectival weak/strong marking cannot satisfy this requirement. The orders in $47 \mathrm{~b}$ and $48 \mathrm{a}$ exemplify earlier constructions that appear to be on the way out in the language.

The genitive case for nonpronominal possessors has fallen out of use (see Lockwood 1977:28 and Thráinsson et al. 2004:62-63), but instead a prepositional phrase tends to be used; the contrast between pronominal and nonpronominal possessors is illustrated in 49. A more recent development is the $s a(r)$ possessive. We do not discuss this further here, but refer to Harries 2015:Ch. 3 .

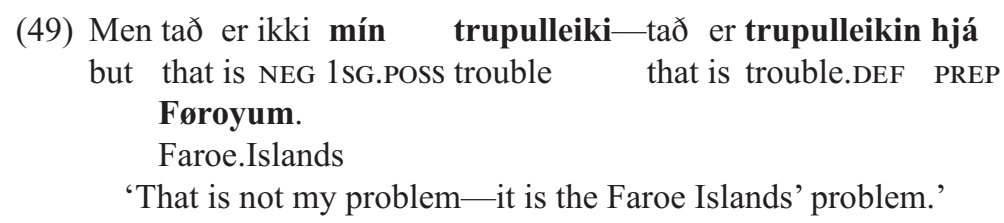

6.3. ANALYSIS. One of the main developments between PDF and its early predecessor is the firm word order that has developed; there is now next to no flexibility. Furthermore, the order is established syntactically, rather than information-structurally. Though there is still some flexibility in the position of possessives, there is no information-structurally privileged position, no grammaticalized discourse function. This does not of course mean that focus cannot be indicated; we expect prosodic marking to have taken over some of this role, and hence it will involve mapping between $p$-structure and i-structure. There are dedicated syntactic elements for both definiteness and indefiniteness; articles have developed and they occur in complementary distribution with other syntactic markers of definiteness. This we take as evidence of the existence of a category D. Furthermore, the feature responsible for definiteness and indefiniteness mark-

\footnotetext{
${ }^{24}$ In the corpus created for Harries 2015, 97\% of the noun phrases containing a possessive pronoun and a premodified possessum had the order in $47 \mathrm{a}$. A referee raises the issue of whether the variation means that Faroese has two coexisting grammars. How to deal with variation of this kind is a key issue, but we do not enter that debate here. We refer the reader to works such as Kroch 1989, 1994, Bresnan \& Aissen 2002, Clark 2004, Sharma et al. 2008, Yang 2010, and Obata et al. 2015 for different views on the issue.
} 
ing is associated with the left edge of the noun phrase in PDF. ${ }^{25}$ As discussed in $§ 2$, the association of a feature with a particular structural position leads us to assume a projecting functional category in c-structure. ${ }^{26}$ Given our assumptions, this means the nonconfigurational flat NP in Old Norse has developed into a configurational articulated DP structure in PDF. This gives the tree in 50 for the noun phrases in $42 b$ and $46 a$.

(50) Present-Day Faroese noun phrase structure

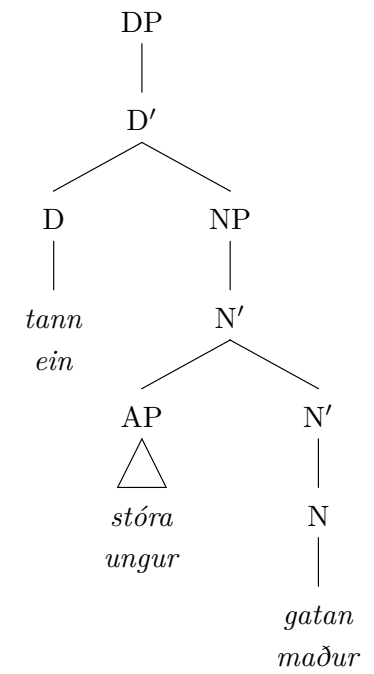

In this analysis, the constraint that definiteness be marked on the left edge is a structural fact; it is because the DP is left-headed. This means that we assume a definite noun may occur under $\mathrm{D}$ if the noun phrase in which it occurs does not contain premodification, to give the tree in 51 .

(51) Present-Day Faroese noun phrase structure: unmodified definite noun<smiles>[Ge]P=PN1c2ccccc21</smiles>

Nouns without a definiteness marker cannot occur in this position since they are unmarked for definiteness rather than marked [DEF - ]. Evidence for this is not just the fact that they cannot on their own function as a referential noun phrase, as illustrated in 46 above, but also the fact that they can actually occur in a definite noun phrase in some contexts, for instance with possessive pronouns. Since nouns without the definite ending are unmarked for definiteness, the indefinite article is always required in an indefinite referential noun phrase.

\footnotetext{
${ }^{25}$ As in other Germanic languages, there are so-called pre-determiners that can precede the determiner and thereby occupy the left edge: allan tann hvita fiskin 'all the white fish.DEF'. We assume that such elements are outside the domain for which the left-edge generalization holds.

${ }^{26}$ Others have accounted for the distribution of definiteness in terms of a percolating left-edge feature (for instance, van der Auwera (1990) and Svenonius (1992)), but do not use this as evidence of a functional projection.
} 
The existence of the functional projection is motivated by the fact that the feature $[\mathrm{DEF} \pm]$ is associated with a structural position, the left edge; it is the fact that a definite noun is marked for this feature that allows it to occur in $\mathrm{D}$. This is parallel to the way in which a finite verb occurs under a clausal functional category in Scandinavian languages to create verb-second, or rather $\mathrm{V}_{\text {finite }}$-second, order. It does not require a process of 'inflectional derivation', as proposed for Danish by Hankamer and Mikkelsen (2002), but relies on functional categories sharing the main categorial features of their associated lexical categories. The functional category D is essentially nominal in nature: it can house only functional features associated with nominals. Grimshaw $(1991,2005)$ discussed this in terms of 'extended projections'. In LFG, the close connection between a functional category and its lexical complement is captured by the notion of CO-HEAD (Bresnan 2001:101-9); the head of the functional category and the head of its lexical complement will be f-structure co-heads. In 52, the $\uparrow=\downarrow$ annotation ensures that the $\mathrm{D}$ and the $\mathrm{N}$ projections are associated with the same $\mathrm{f}$-structure. Thereby the f-structure associated with D contributes [DEF +] and [NUM SG] to the resulting f-structure in 53, and the one associated with $\mathrm{N}$ contributes [PRED 'mystery'] and $[\mathrm{NUM} \mathrm{SG}] .{ }^{27}$
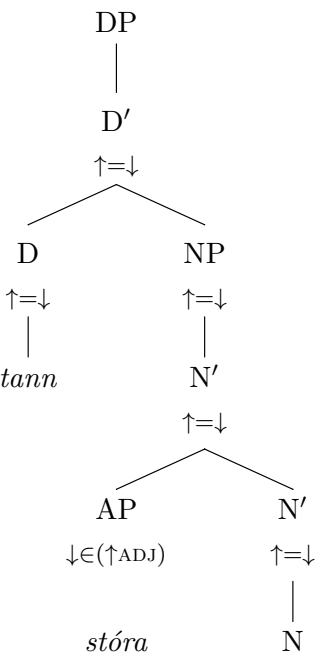

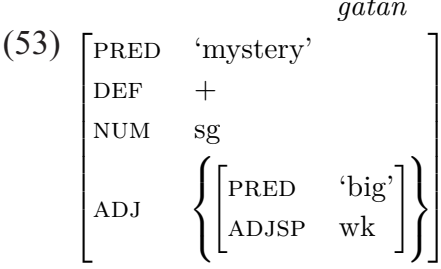

One challenge for any account of noun phrases in Mainland Scandinavian is how to handle the fact that a syntactic determiner is required when there is premodification, and this applies also to Faroese. ${ }^{28} \mathrm{~A}$ broad range of analyses aiming to account for the

\footnotetext{
${ }^{27}$ The fact that the value for ADJ is a set (see 2) is indicated with \{\} in the feature matrix, and we have captured the weak/strong distinction by means of a feature ADJSP.

${ }^{28}$ The issue is generally discussed in relation to definite noun phrases, not because adjectives in indefinite noun phrases do not need to be preceded by a syntactic determiner, but because a syntactic determiner is al-
} 
requirement for a prenominal adjective to be preceded by a determiner exist in the literature; a representative sample of solutions using the formal tools of the selected frameworks are: Cooper 1984, Hellan 1986, Holmberg 1992, Svenonius 1992, Delsing 1993, Börjars 1998, Börjars \& Donohue 2000. There are many more recent analyses, but they tend to involve developments and refinements of earlier proposals.

We assume that the explanation is historical, that this is a reflex of the time when the syntactic determiner was a specifier of the adjective rather than of a nominal constituent. In our view, what we have here is a piece of linguistic structure whose real raison d'être is diachronic. In this sense it could be considered an instance of what Dryer (2006:213) had in mind when, having drawn a fundamental distinction between descriptive and explanatory theories, he wrote 'functional explanations - explanations for why languages are the way they are-apply primarily at the level of language change'. Though the explanation for the distribution of the syntactic definiteness marker in PDF is historical, the way it is integrated has changed over time. The element in question was originally associated with the adjective and occurred immediately to its left, frequently following the noun. As word order became fixed, with the adjective prenominal, the element became associated with the left edge of the noun phrase, rather than with just the adjective. The increasingly frequent prenominal position of the adjective and its associated specifier can then be described as the bridging context for its development into a $\mathrm{D}$ element. It thus represents an example of STRUCTURAL PERSISTENCE, extending a term introduced by Hopper (1991) and applied in an extended structural sense by, for instance, Breban (2009) and Börjars and colleagues (2013). At the same time, however, it is clear that the structure of APs and the connection with the syntactic definiteness marker has changed, for instance in that there is no requirement for the definiteness marker when an adjective occurs postnominally. This means that it is no longer appropriate to analyze the element as forming a constituent with the adjective, as assumed for Old Norse in 23. The obligatoriness of a determiner before an adjective in our analysis comes down to a structural requirement to have an element marked for definiteness in the $\mathrm{D}$ position on the left edge, and the weak/strong feature on the adjective cannot fulfill this role. It is interesting at this point to note the analysis based on fundamentally different assumptions from ours by Leu (2008). He does not deal with historical data, but assumes for the present-day varieties of both Mainland Scandinavian and English that the definite article forms a constituent with the adjective phrase. For English, this means that the definite article inside the extended projection of the adjective 'licenses the non-pronunciation of the definite article in $\mathrm{D}^{\mathrm{o}}$ ' (Leu 2008:48). Give the assumptions we make, this analysis is not appropriate for the modern data we are considering here.

Though there is a sense in which the syntactic definiteness marker occurs to satisfy a constraint for definiteness to be overtly expressed on the left edge, it is not an expletive element as in some analyses of other Scandinavian languages discussed above. In functional terms, the syntactic and the morphological definiteness markers contribute the same feature values. Since D, under which a syntactic determiner is found, and N, which houses the definite noun in a noun phrase also containing a syntactic determiner, are co-heads, they both contribute features to the same f-structure, as illustrated in 52 above. The fact that they contribute the same feature is not a problem; it will be the case

ways required for referential indefinite noun phrases, whether they involve a premodifier or not. However, Börjars and Donohue (2000:340-42) argue that at least for Swedish, it holds also for indefinite noun phrases, as they can occur without an article in predicative position, except when they are preceded by an adjective. 
not just for the DEF feature, but also for NUM and GEND. In this sense, we consider 'double definiteness' a relatively superficial phenomenon; in Faroese, Swedish, and Norwegian the determiner and the noun agree not just for number and gender, but also for definiteness, whereas in Danish, which does not show double definiteness, the syntactic definiteness markers do not require the noun to agree for definiteness. ${ }^{29}$ We do not believe that Danish has a fundamentally different noun phrase structure from Swedish, Norwegian, and Faroese. The development of double definiteness in Faroese is particularly interesting since it appears to have become obligatory some time after 1900. This means that it happened at a time when it can be assumed to have been under heavy influence from Danish, a language that does not have double definiteness.

7. Conclusions. We have argued here that a category D has developed between Old Norse and early Faroese and that subsequently this category has come to head a DP projection in Present-Day Faroese. The same development can be assumed to have taken place in the other Scandinavian languages. In our view, these are two distinct steps. A category D can be said to be developing when definiteness marking becomes obligatory and when there is complementary distribution between independent markers that encode the same feature. At this stage, however, there is no independent empirical reason to assume a phrasal projection associated with this category. Nor, from a theoretical point of view, is it necessary to postulate that all categories project to the phrasal level. Only when the functional feature becomes associated with a particular structural position do we assume that the category projects to the phrasal level. This distinguishes our approach from that taken by Lander and Haegeman (2013) and others, where the existence of a category D is in itself evidence for a DP. This in turn reflects our broader theoretical view that there is a valuable and empirically supported distinction to be drawn between items that just give realization to grammatical or semantic features and those that define larger structural units such as phrases. A single item such as a demonstrative or a definite article may of course in a given language fulfill both functions, but the link is not a necessary one, as indeed our historical evidence shows. The distinction we have in mind is akin to that drawn by Pollard and Sag (1994:44-45) between a 'head' and a "marker', where the latter is defined as 'a word that is "functional" or "grammatical" as opposed to substantive, in the sense that its semantic content is purely logical in nature (perhaps even vacuous). A marker, so-called because it formally MARKs the constituent in which it occurs, combines with another element that heads that constituent'. From our point of view, the crucial idea is that at a given historical moment an item can have the role of a marker and only at a later point and as a result of subsequent changes come to function as a syntactic head. In this sense our account offers a diachronic complement to the exclusively synchronic arguments of Pollard and Sag (1994).

The connection between the feature $[\mathrm{DEF} \pm]$ and a structural position is then crucial to our analysis. We assume that this connection holds true for all of the Scandinavian languages. The difference between Faroese, Norwegian, and Swedish, on the one hand, and Danish, on the other, is a matter of agreement. Adjectives in Icelandic have retained from Old Norse their capacity to satisfy the requirement that a referential noun phrase has semantic definiteness marking on the left, whereas in the other languages the pres-

\footnotetext{
${ }^{29}$ Other authors, for instance Julien (2005), have argued that the two elements contribute different features, but we believe the effects they refer to cannot be attributed separately to the two elements, but are the result of a number of interacting factors. On the notion of historical competition between the syntactic and the morphological definiteness markers, see Dahl 2010.
} 
ence of weak or strong marking on adjectives is a formal residue of an earlier diachronic stage, but the functional role has passed to the definiteness marker on the determiner or the noun.

Both of the steps we postulate constitute subtypes of grammaticalization as discussed in $\S 1$ : in the first the particular grammatical feature [DEF] comes to be associated with a single syntactic category, while the second involves the creation of new grammatical structure. The process most commonly described as grammaticalization, that is, the bleaching of an element such as a demonstrative to become a pure definiteness marker, had started before the earliest remaining sources, but was still going on during the period we have considered. The development of tann in Faroese is an example. This 'bleaching' of the item's meaning is generally described as a loss. However, a different perspective takes the functional feature or the emergent category as the point of departure and describes the change as having resulted in an overt expression for the feature, and the change is hence considered a gain rather than a loss. In the words of von Fintel $(1995: 185)$ :

[w] hat this process [sc. of grammaticalization] does is enrich the inventory of functional categories in a language. Before what we had was a small number of (implicit) functional categories and a certain number of logical items (which weren't yet functional morphemes). Afterwards, we have a new functional item. Functional meanings that before were just floating around without an overt foothold can get one this way.

More specifically in the case that interests us here, the feature [DEF] existed in Old Norse, but did not have dedicated obligatory exponence; this it gains as the result of grammaticalization.

This approach assumes that there is a fixed universal inventory of functional semantic categories such as [DEF], which von Fintel equates to high logical types, but that languages can vary across time and space in the way they give realization to these categories. In his words: 'In grammaticalization, the functional system of a language gets richer, although overall no new meanings get created' $(1995: 185)$. There is no reason to challenge this assumption in the particular instance that we have studied in this article since definiteness can reasonably be subsumed within even a very restricted set of universal operators, but we would not go as far as to assume all functional features are universal. ${ }^{30}$

One of the great benefits of accounts like that offered by von Fintel is that they provide a way to link the patterns of semantic 'bleaching' evident in the processes dubbed grammaticalization to the tradition of formal semantic analysis rather than seeing such developments as implicitly challenging formal approaches to linguistic analysis. What they do not offer is a specific mapping between the semantics and the syntax. Thus, von Fintel (1995:183) notes that the mapping can be achieved in a variety of ways, including universal empty D heads but also including type-shifting, appropriate use of features or meanings associated directly with constructions. The data we have analyzed here begin to resolve that question by demonstrating that the emergence of feature structure is a precursor to, and both logically and chronologically distinct from, the emergence of full syntactic configurationality.

Once we have a category D, however, it can provide a locus for the development of related elements. If there is a dedicated element for the feature value [DEF +], it is natural for an element with the feature value [DEF - ] to develop and to join the same category. The $\mathrm{D}$ that has come about as a result of the development of a definite article can

\footnotetext{
${ }^{30}$ A referee points out that it is unlikely that we would want all languages to have features for the kind of verbal aspect that is found in the Slavic languages, for instance.
} 
now also accommodate an indefinite article. It is what Bisang (1996) refers to as an ATTRACTOR POSITION. Strictly speaking, it is only at the stage when we have both definite and indefinite articles that we are entitled to talk of one feature [DEF] with the two contrasting values plus and minus. Before that we simply have a monovalent feature [DEF]. Such a conclusion is supported by two convergent lines of argument. First, even in languages where it is reasonable to postulate the presence of both definite and indefinite articles, they emerge historically from different sources and at different times. Second, in the sample compiled and analyzed by Dryer (2011a,b), there are ninety-eight languages that have only a definite article and no indefinite one and forty-five that have an indefinite but no definite article. In other words, in typological terms there is no necessary connection between the presence of the two kinds of article within a single language. In the language we have considered here, it is clearly the case that [DEF - ] developed later. The early Faroese text has obligatory marking for [DEF + ], but it is only in the language of the 1890 s that we find obligatory [DEF - ] marking.

We return now to the analysis of the development at clausal level between IndoEuropean and Germanic outlined by Kiparsky (1995) (see 7 in §3). It is interesting to note the parallels between this and our analysis of the development of noun phrase structure in the same language family. At both levels, a projecting functional category has developed. In both cases, the functional category is motivated by a functional feature, $[\mathrm{FIN}]$ and $[\mathrm{DEF}]$, being associated with a particular position. The fact that the category houses a feature rather than a specific element means that lexical elements with marking for the specific feature can occur in the same position; finite verbs and definite nouns occur under the functional category. Furthermore, in both clauses and noun phrases an information-structurally defined initial position has grammaticalized as a syntactically defined position. This example provides a further context in which Pollard and Sag's (1994) concept of a marker comes into play. Indeed, they introduce the concept precisely in order to deal with the syntax of items like English that, than, and as. We can now say that at Kiparsky's intermediate stage, the grammaticalizing subordination items have attained the status of markers, but that they subsequently go on to achieve full status as a projecting head and hence to determine the overall categorization of the clause as a CP. More generally, we would suggest that the development from marker to projecting head represents a natural trajectory of syntactic change.

It has been suggested in the literature that the development of an article system is related to the loss of case (Holmberg 1993, Giusti 2015). Like Anward and Swedenmark (1997), we do not believe that there is a direct relationship between the two changes. Faroese and Norwegian show close similarities with respect to the distribution and development of definiteness markers, and yet their case systems are quite different. Norwegian has lost case except on some pronouns, but Faroese has a productive system of nominative, accusative, and dative, with genitive disappearing except on pronouns. Leiss $(2000,2007)$, by contrast, links the development of (in)definiteness with the decline of aspectual markers. Perridon and Sleeman (2011:4) provide convincing arguments against this hypothesis, not the least of these being the fact that there are over four centuries between the loss of the aspectual prefixes that Leiss argues are implicated and the development of definiteness. In the analysis presented here, the development of definiteness marking in Scandinavian is anchored in discourse structure, and in particular the role of the left edge of a constituent as the marker of focus or topic, as explored within the noun phrase by, for instance, Longobardi (1994, 2001). Changes in case marking are independent developments, often triggered by sound change. What both 
changes have in common is their reliance on configurationality to express content that previously was not overtly marked or was marked by morphological means. Loss of case and the development of articles may thus converge over time as they do in the history of many languages, but the processes and pace of the changes are independent of each other.

More generally, our account argues the case on diachronic grounds for a parallel architecture such as that which characterizes LFG in the spirit of Vincent (2001). Languages are made up of separate facets-informational-structural, semantic, syntactic, morphological, and phonological—which are defined by different types of analytical primitives and which come together in different combinations in different languages. This separation of dimensions allows c-structure to be defined with reference only to order and constituency, and hence the distinction between configurational and nonconfigurational phrases can be made in a straightforward fashion. It also follows from this view that change may operate at different speeds and in different ways within each domain, leading to a wide variety of historical profiles just as there exist a wide variety of possible languages. It is one such profile that has been the focus of attention in the present study.

\section{SOURCES}

Barl: Barlaams ok Josaphats saga. Ed. by Magnus Rindal. 1981. Oslo: Norsk historisk kjeldeskrift-institutt. Cited here from Faarlund 2004.

BN: Brennu-Njáls saga. (Islenzk fornrit XII.) Ed. with introduction and notes by Einar Ól. Sveinsson. 1956. Reykjavík: Hið Íslenzka Fornritafélag. References are to Chapter.Line in this edition.

Egil: Egils saga. Ed. by Bjarni Einarsson. 2003. London: University College London, Viking Society for Northern Research. References are to Chapter.Line in this edition. Online: http://vsnrweb-publications.org.uk/.

ER: Eiriks saga rauða in Eyrbyggja saga. (Islenzk fornrit IV.) Ed. with introduction and notes by Einar Ól. Sveinsson and Matthias Pórðarsson. 1935. Reykjavík: Hið Íslenzka Fornritafélag. References are to Chapter.Line in this edition.

Gunnl: Gunnlaugs saga ormstungu. Ed. by Peter G. Foote and with translation by Randolph Quirk. 1957. London: Thomas Nelson and Sons. References are to Chapter.Line in this edition. Online: http://vsnrweb-publications.org.uk/.

Gylf: Gylfaginning. In Snorre Sturlusons Edda. 2nd edn. Ed. with introduction and notes by Anthony Faulkes. 2005. London: University College London, Viking Society for Northern Research. References are to Page.Line in this edition. Online: http://vsnrweb -publications.org.uk/.

Har: Haralds saga hins hárfagra. In Heimskringla eða: Sögur Noregs konunga, vol 1. Ed. by Nils Linder og K. A. Haggson. 1870. Uppsala: W Schultz. References are to Chapter.Line in this edition.

Háv: The Poetic Edda. Hávamál. References are to Verse.Line.

Heims: Heimskringla. From Gordon 1927. References are to Chapter.Line in the selections there. Information about the edition from which the text is taken can be found at the beginning of the chapter.

Hró: Hrólfs saga Kraka. From Gordon 1927. References are to Chapter.Line in the selections there. Information about the edition from which the text is taken can be found at the beginning of the chapter.

Lax: Laxdoela saga in Laxdoela saga. (Islenzk fornrit V.) Ed. with introduction and notes by Einar Ól. Sveinsson. 1934. Reykjavík: Hið Íslenzka Fornritafélag. References are to Page.Line in this edition.

Lib Isl: Libellus Islandorum. From Gordon 1927. References are to Chapter.Line in the selections there. Information about the edition from which the text is taken can be found at the beginning of the chapter. 
Sno Edd: Snorre Sturlusons Edda. From Gordon 1927. References are to Chapter.Line in the selections there. Information about the edition from which the text is taken can be found at the beginning of the chapter.

Porf: The expedition of Porfinn Karlsefni. From Gordon 1927. References are to Chapter.Line in the selections there. Information about the edition from which the text is taken can be found at the beginning of the chapter.

VG: Viga-Glúms saga in Eyfirðinga sögur. (Islenzk fornrit IX.) Ed. with introduction and notes by Jónas Kristjánsson. 1956. Reykjavík: Hið Íslenzka Fornritafélag. References are to Chapter.Line in this edition.

\section{REFERENCES}

Abaev, V. I. 1949. Osetinskij jazyk i fol'klor, vol. 1. Moscow: Akademija Nauk SSSR.

Aboh, Enoch O.; Norbert Corver; Marina Dyakonova; and Marjo van Koppen. 2010. DP-internal information structure: Some introductory remarks. Lingua 120.782 801. DOI: 10.1016/j.lingua.2009.02.010.

Abraham, Werner, and Elisabeth Leiss. 2007. On the interfaces between (double) definiteness, aspect and word order in Old and Modern Scandinavian. Working Papers in Scandinavian Syntax 80.17-44.

Abraham, Werner; Elisabeth Stark; and Elisabeth Leiss. 2007. Introduction. In Stark et al., $1-20$.

Andersen, HenNing. 2006. Grammation, regrammation, and degrammation: Tense loss in Russian. Diachronica 23.231-58. DOI: 10.1075/dia.23.2.02and.

Antonsen, Elmer H. 1967. 'Proto-Scandinavian' and Common Nordic. Scandinavian Studies 39.16-39. Online: http://www.jstor.org/stable/40916825.

Antonsen, Elmer H. 1975. A concise grammar of the older Runic inscriptions. Tübingen: Max Niemeyer.

Anward, Jan, and John Swedenmark. 1997. ¡Kasus nej, bestämdhet ja! Studier i svensk språkhistoria 4, ed. by Patrik Åström, 21-34. Stockholm: Institutionen för nordiska språk.

Asudeh, Ash, and Ida Toivonen. 2009. Lexical-functional grammar. The Oxford handbook of linguistic analysis, ed. by Bernd Heine and Heiko Narrog, 425-58. Oxford: Oxford University Press.

Austin, Peter, and Joan Bresnan. 1996. Non-configurationality in Australian Aboriginal languages. Natural Language and Linguistic Theory 14.215-68. DOI: 10.1007/BF001 33684 .

BaKker, StePhanie. 2009. The noun phrase in Ancient Greek: A functional analysis of the order and articulation of NP constituents in Herodotus. Leiden: Brill.

Barnes, Michael P. 2008. A new introduction to Old Norse, part 1: Grammar. 3rd edn. London: Viking Society for Northern Research.

Barnes, Michael P., and Eivind Weyhe. 1994. Faroese. The Germanic languages, ed. by Ekkehard König and Johan van der Auwera, 190-218. London: Routledge.

Bernstein, Judy B. 2001. Focusing the 'right' way in Romance determiner phrases. Probus 13.1-29. DOI: 10.1515/prbs.13.1.1.

BisANG, WALTER. 1996. Areal typology and grammaticalization: Processes of grammaticalization based on nouns and verbs in east and mainland South East Asian languages. Studies in Language 20.519-97. DOI: 10.1075/sl.20.3.03bis.

Bolinger, Dwight. 1967. Adjectives in English: Attribution and predication. Lingua 18.1-34. DOI: 10.1016/0024-3841(67)90018-6.

BörJARS, Kersti. 1998. Feature distribution in Swedish noun phrases. Oxford: Blackwell.

BörJars, Kersti; Erika Chisarik; and John Payne. 1999. On the justification for functional categories in LFG. Proceedings of the LFG '99 Conference. Online: http:// cslipublications.stanford.edu/LFG/LFG4-1999/lfg99borjarsetal.pdf.

Börjars, Kersti; David Denison; Grzegorz Krajewski; and Alan Scott. 2013. Expression of possession in English: The significance of the right edge. Morphosyntactic categories and the expression of possession, ed. by Kersti Börjars, David Denison, and Alan Scott, 123-48. Amsterdam: John Benjamins.

BörJars, Kersti, and Mark Donohue. 2000. Much ado about nothing: Features and zeroes in Germanic noun phrases. Studia Linguistica 54.309-53. DOI: 10.1111/1467-9582.t01 $-1-00069$. 
Börjars, Kersti, and Pauline Harries. 2008. The clitic-affix distinction, historical change, and Scandinavian bound definiteness marking. Journal of Germanic Linguistics 20.289-350. DOI: 10.1017/S1470542708000068.

BörJars, Kersti, and John PAYNe. 2013. Dimensions of variation in the expression of functional features: Modelling definiteness in LFG. Proceedings of the LFG '13 Conference, 152-70. Online: http://cslipublications.stanford.edu/LFG/18/papers/lfg13borjarspayne .pdf.

BošKOVIĆ, ŽELJKO. 2005. On the locality of left branch extraction and the structure of NP. Studia Linguistica 59.1-45. DOI: 10.1111/j.1467-9582.2005.00118.x.

BošKović, ŽELJKo. 2008. What will you have, DP or NP? North East Linguistic Society (NELS) 37.101-14.

BošKović, ŽELJKO. 2009. More on the no-DP analysis of article-less languages. Studia Linguistica 63.187-203. DOI: 10.1111/j.1467-9582.2009.01158.x.

BošKović, ŽEluKo. 2010. On NPs and clauses. Discourse and grammar: From sentence types to lexical categories, ed. by Günther Grewendorf and Thomas E. Zimmermann, 179-242. Berlin: De Gruyter Mouton.

Braunmüller, Kurt. 1994. Some typological trends in the development of the noun phrase in Germanic languages. Language change and language structure: Older Germanic languages in a comparative perspective, ed. by Toril Swan, Endre Mørck, and Olaf Jansen Westvik, 27-50. Berlin: Mouton de Gruyter.

Breban, Tine. 2009. Structural persistence: A case based on the grammaticalization of English adjectives of difference. English Language and Linguistics 13.77-96. DOI: 10 $.1017 / \mathrm{S} 1360674308002888$.

Bresnan, JoAn. 1982. Control and complementation. Linguistic Inquiry 13.343-434. Online: http://www.jstor.org/stable/4178286.

BRESNAN, JoAn. 2001. Lexical-functional syntax. Oxford: Blackwell.

Bresnan, JoAn, and Judith Aissen. 2002. Optimality and functionality: Objections and refutations. Natural Language and Linguistic Theory 20.81-95. DOI: 10.1023/A:101 4222605182.

Chierchia, Gennaro. 1998. Reference to kinds across languages. Natural Language Semantics 6.339-405. DOI: 10.1023/A:1008324218506.

Clark, Brady. 2004. A stochastic optimality theory approach to syntactic change. Stanford, CA: Stanford University dissertation.

CoOPER, Robin. 1984. Svenska nominalfraser och kontext-fri grammatik. Nordic Journal of Linguistics 7.115-44. DOI: 10.1017/S0332586500001177.

Curme, George O. 1910. The origin and growth of the adjective declension in Germanic. The Journal of English and Germanic Philology 9.439-82. Online: http://www.jstor .org/stable/27700053.

Dahl, Östen. 2004. Definite articles in Scandinavian: Competing grammaticalization processes in standard and non-standard varieties. Dialectology meets typology: Dialect grammar from a cross-linguistic perspective, ed. by Bernd Kortmann, 147-80. Berlin: Mouton de Gruyter.

Dahl, Östen. 2010. Grammaticalization in the north: Noun phrase morphosyntax in Scandinavian vernaculars. (RAPPLING 1.) Stockholm: Stockholm University.

Dalrymple, Mary. 2001. Lexical functional grammar. New York: Academic Press.

Delsing, Lars-Olof. 1993. The internal structure of noun phrases in the Scandinavian languages. Lund: Lund University dissertation.

Delsing, Lars-Olof. 1994. 'Hans sjukt ben'—om starka och svaga adjektiv i Fornsvenskan. Språkbruk, grammatik och språkförändring: En festskrift till Ulf Teleman, ed. by Nils Jörgensen, Christer Platzack, and Jan Svensson, 99-108. Lund: Lund University.

Devine, Andrew M., and Laurence D. Stephens. 2006. Latin word order: Structured meaning and information. Oxford: Oxford University Press.

Dik, Helma. 2007. Word order in Greek tragic dialogue. Oxford: Oxford University Press.

Dixon, Robert M. W. 1972. The Dyirbal language of North Queensland. Cambridge: Cambridge University Press.

Dryer, MatThew S. 2006. Descriptive theories, explanatory theories, and basic linguistic theory. Catching language: Issues in grammar writing, ed. by Felix Ameka, Alan Dench, and Nicholas Evans, 207-34. Berlin: Mouton de Gruyter. 
Dryer, Matthew S. 2011a. Definite articles. The world atlas of language structures online, ed. by Matthew S. Dryer and Martin Haspelmath, Ch. 37. Munich: Max Planck Digital Library. Online: http://wals.info/chapter/37. Accessed March 8, 2013.

DRYer, MatTHEw S. 2011b. Indefinite articles. The world atlas of language structures online, ed. by Matthew S. Dryer and Martin Haspelmath, Ch. 38. Munich: Max Planck Digital Library. Online: http://wals.info/chapter/38. Accessed March 8, 2013.

FaARlund, Jan TerJe. 1990. Syntactic change: Toward a theory of historical syntax. Berlin: Mouton de Gruyter.

FaARLund, JAN TerJe. 2004. The syntax of Old Norse. Oxford: Oxford University Press.

FAarlund, JAn TerJe. 2007. From clitic to affix: The Norwegian definite article. Working Papers in Scandinavian Syntax 79.21-46.

FAARLUnd, JAN TERJE. 2009. On the history of definiteness marking in Scandinavian. Journal of Linguistics 45.617-39. DOI: 10.1017/S0022226709990041.

FALK, YeHUdA. 2001. Lexical-functional grammar. Stanford, CA: CSLI Publications.

Fischer, Olga; Ans van Kemenade; Willem Koopman; and Wim Van der WurfF. 2000. The syntax of Early English. Cambridge: Cambridge University Press.

Foote, P. G. (ed.) 1957. Gunnlaugs saga ormstungu. London: Thomas Nelson and Sons.

FUKUI, NAOMI. 1986. A theory of category projection and its applications. Cambridge, MA: MIT dissertation.

Fukui, Naomi, and Margaret Speas. 1986. Specifiers and projections. MIT Working Papers in Linguistics (Papers in theoretical linguistics) 8.128-72.

Giusti, Giuliana. 1996. Is there a FocusP and a TopicP in the noun phrase structure? University of Venice Working Papers in Linguistics 6.2.105-28.

Giusti, Giuliana. 2015. Nominal syntax at the interfaces: A comparative analysis of languages with articles. Newcastle upon Tyne: Cambridge Scholars Press.

Gordon, ERIC V. 1927. An introduction to Old Norse. Oxford: Oxford University Press.

GrimshaW, JANE. 1991. Extended projections. Waltham, MA: Brandeis University, MS.

Grimshaw, JANE. 2005. Words and structure. Stanford, CA: CSLI Publications.

Haegeman, Liliane. 2004. DP-periphery and clausal periphery: Possessor doubling in West Flemish. Peripheries, ed. by David Adger, Cecile de Cat, and George Tsoulas, 211-40. Dordrecht: Kluwer.

Hankamer, JoRge, and Line Hove MikKelsen. 2002. A morphological analysis of definite nouns in Danish. Journal of Germanic Linguistics 14.137-75. DOI: 10.1017/S14705 42702000077.

Harries, PAUline. 2015. The distribution of definiteness markers and the growth of syntactic structure from Old Norse to Modern Faroese. Manchester: The University of Manchester dissertation.

Harris, Martin. 1980. The marking of definiteness: A diachronic perspective. Papers from the 4th International Conference on Historical Linguistics, ed. by Elizabeth Closs Traugott, Rebecca Labrum, and Susan Shepherd, 75-86. Amsterdam: John Benjamins.

Heinrichs, Heinrich Matthias. 1954. Studien zum bestimmten Artikel in den germanischen Sprachen. Giessen: Wilhelm Schmitz.

Hellan, LaRs. 1986. The headedness of NPs in Norwegian. Features and projections, ed. by Pieter Muysken and Henk van Riemsdijk, 89-122. Dordrecht: Foris.

Heltoft, LaRs. 2010. Paradigmatic structure and reanalysis: From NPs to DPs in Scandinavian. Acta Linguistica Hafniensia: International Journal of Linguistics 42.11-25. DOI: 10.1080/03740463.2010.486912.

Heusler, Andreas. 1921. Altisländisches Elementarbuch. Heidelberg: Carl Winters Universitätsbuchhandlung.

HilPERT, MARTin. 2010. What can synchronic gradience tell us about reanalysis? Verb-first conditionals in written German and Swedish. Gradience, gradualness and grammaticalization, ed. by Elizabeth Closs Traugott and Graeme Trousdale, 181-201. Amsterdam: John Benjamins.

Himmelmann, Nikolaus P. 1997. Deiktikon, Artikel, Nominalphrase: Zur Emergenz syntaktischer Struktur. Tübingen: Max Niemeyer.

Holmberg, ANDERS. 1992. On the structure of predicate NP. Papers from the Workshop on the Scandinavian Noun Phrase, ed. by Anders Holmberg, 58-71. Umeå: Department of General Linguistics, University of Umeå.

HolmberG, ANDERs. 1993. On the representation of Case. GLOW-Newsletter 30.36-37. 
Hopper, Paul J. 1991. On some principles of grammaticalization. Approaches to grammaticalization, vol. 2: Focus on types of grammatical markers, ed. by Elizabeth Closs Traugott and Bernd Heine, 17-35. Amsterdam: John Benjamins.

JøHndal, Marius L. 2012. Non-finiteness in Latin. Cambridge: University of Cambridge dissertation.

Julien, MARIT. 2005. Nominal phrases from a Scandinavian perspective. Amsterdam: John Benjamins.

KIPARSKY, PAUl. 1995. Indo-European origins of Germanic syntax. Clause structure and language change, ed. by Ian G. Roberts and Adrian Battye, 140-67. Oxford: Oxford University Press.

KROCH, ANTHONY S. 1989. Reflexes of grammar in patterns of language change. Language Variation and Change 1.199-244. DOI: 10.1017/S0954394500000168.

Kroch, Anthony S. 1994. Morphosyntactic variation. Chicago Linguistic Society (Parasession on variation and linguistic theory) 30.2.180-201.

Kroeger, Paul R. 1993. Phrase structure and grammatical relations in Tagalog. Stanford, CA: CSLI Publications.

LANDER, ERIC, and Liliane HaEgeman. 2013. Old Norse as an NP language, with observations on the common Norse and Northwest Germanic Runic inscriptions. Transactions of the Philological Society 112.279-318. DOI: 10.1111/1467-968X.12022.

Leiss, Elisabeth. 2000. Artikel und Aspekt: Die grammatischen Muster von Definitheit. Berlin: De Gruyter.

Leiss, Elisabeth. 2007. Covert patterns of definiteness/indefiniteness and aspectuality in Old Icelandic, Gothic, and Old High German. In Stark et al., 73-102.

Leu, Thomas. 2008. The internal syntax of determiners. New York: New York University dissertation. Online: http://ling.auf.net/lingbuzz/000745.

Lockwood, William B. 1977. An introduction to Modern Faroese. Tórshavn: Føroya Skúlabókagrunnur.

LOHNDAL, TERJE. 2007. On the structure and development of nominal phrases in Norwegian. In Stark et al., 287-310.

LONGOBARDI, GIUSEPPE. 1994. Reference and proper names. Linguistic Inquiry 25.609-65. DOI: $10.2307 / 2025107$.

LONGOBARDI, GIUSEPPE. 2001. The structure of DPs: Some principles, parameters and problems. The handbook of contemporary syntactic theory, ed. by Mark Baltin and Chris Collins, 562-603. Oxford: Blackwell.

LundeBy, EINAR. 1965. Overbestemt substantiv i norsk og de andre nordiske språk. Oslo: Universitetsforlaget.

Lyons, Christopher. 1999. Definiteness. Cambridge: Cambridge University Press.

MitChell, BruCe. 1985. Old English syntax, vol. 1: Concord, the parts of speech, and the sentence. Oxford: Clarendon.

Nielsen, Hans Frede. 1989. The Germanic languages: Origins and early dialectal interrelationships. Tuscaloosa: University of Alabama Press.

NordLINGer, RACHEL. 1998. Constructive case: Evidence from Australian languages. Stanford, CA: CSLI Publications.

Obata, Miki; Samuel Epstein; and Marlyse Baptista. 2015. Can crosslinguistically variant grammars be formally identical? Third factor underspecification and the possible elimination of parameters of UG. Lingua 156.1-16. DOI: 10.1016/j.lingua.2014.12 .003 .

Perridon, Harry. 1989. Reference, definiteness and the noun phrase in Swedish. Amsterdam: University of Amsterdam dissertation.

Perridon, Harry, and Petra Sleeman. 2011. The noun phrase in Germanic and Romance. The noun phrase in Romance and Germanic, ed. by Harry Perridon and Petra Sleeman, 1-21. Amsterdam: John Benjamins.

Plank, Frans. 2003. Double articulation. Noun phrase structure in the languages of Europe, 337-96. Berlin: Mouton de Gruyter.

Platzack, Christer. 1991. Review of Faarlund 1990. Arkiv för nordisk filologi 106.18384.

Platzack, Christer. 2008. Left branch extraction of nominal modifiers in old Scandinavian. Grammatical change and linguistic theory: The Rosendal papers, ed. by Thórhallur Eythórsson, 357-74. Amsterdam: John Benjamins. 
Pollard, CARL, and Ivan SAG. 1994. Head-driven phrase structure grammar. Stanford, CA: CSLI Publications.

Radatz, Hans-Ingo. 2001. Die Semantik der Adjektivstellung. Tübingen: Max Niemeyer.

RatKus, Artūras. 2010. The adjective inflection in Gothic and early Germanic: Structure and development. Cambridge: Cambridge University dissertation.

RENZI, LORENZO. 1992. Le développement de l'article en roman. Revue Roumaine de Linguistique 37.161-76.

Riebler, Michael. 2011. Typology and evolution of adjective attribution marking in the languages of northern Eurasia. Leipzig: Universität Leipzig dissertation. Online: http://omnibus.uni-freiburg.de/ mr5496/downl/RIESSLER2011.pdf.

Roberts, IAN G., and Anna Roussou. 2003. Syntactic change: A minimalist approach to grammaticalization. Cambridge: Cambridge University Press.

Roehrs, Dorian, and Christopher D. SAPr. 2004. The rise of the suffixal article in the early North Germanic DP. Western Conference on Linguistics (WECOL) 16.290-301. Online: http://www.fresnostate.edu/artshum/linguistics/documents/WECOL\%202004 \%20VOLUME\%2016.pdf.

RÖGNVALDSSON, EIRÍKUR. 1995. Old Icelandic: A non-configurational language? NOWELE 26.3-29. DOI: 10.1075/nowele.26.01rog.

Sadler, Louisa, and Douglas J. Arnold. 1994. Prenominal adjectives and the phrasal/ lexical distinction. Journal of Linguistics 30.187-226. DOI: 10.1017/S002222670001 6224.

Sharma, Devyani; Joan Bresnan; and Ashwini Deo. 2008. Variation and change in the individual: Evidence from the survey of English dialects. Language in flux: Dialogue coordination, language variation, change and evolution, ed. by Robin Cooper and Ruth Kempson, 265-321. London: College Publications.

SkrZyPeK, Dominika. 2010. Between a demonstrative and an article: The status of $-i n$ in Old Swedish. Folia Scandinavica 11.145-62.

Stark, Elisabeth; Elisabeth Leiss; and Werner Abraham (eds.) 2007. Nominal determination: Typology, context constraints, and historical emergence. Amsterdam: John Benjamins.

Stockwell, Robert P., and Karn King. 1993. Review of Faarlund 1990. Nordic Journal of Linguistics 16.60-68. DOI: 10.1017/S0332586500002699.

Stowell, Tiмотну. 1989. Subjects, specifiers, and X-bar theory. Alternative conceptions of phrase structure, ed. by Mark Baltin and Anthony Kroch, 232-62. Chicago: University of Chicago Press.

Stroh-Wollin, Ulla. 2009. On the development of definiteness markers in Scandinavian. Working Papers in Scandinavian Syntax 83.1-25.

Stroh-Wollin, Ulla, and Rico Simke. 2014. Strong and weak adjectives in Old Swedish. Adjectives in Germanic and Romance, ed. by Petra Sleeman, Freek Van de Velde, and Harry Perridon, 95-112. Amsterdam: John Benjamins.

Svenonius, Peter. 1992. The distribution of definite marking. Papers from the Workshop on the Scandinavian Noun Phrase, ed. by Anders Holmberg, 135-64. Umeå: Department of General Linguistics, University of Umeå.

Szabolcsi, Anna. 1987. Functional categories in the noun phrase. Approaches to Hungarian 2, ed. by István Kenesei, 167-90. Szeged: JATE.

THOMPSON, SANDRA A. 1988. A discourse approach to the cross-linguistic category 'adjective'. Explaining language universals, ed. by John Hawkins, 167-85. Oxford: Blackwell.

Thráinsson, Höskuldur; Hualmar P. Petersen; Jógvan í lon Jacobsen; and Zakaris Svabo Hansen. 2004. Faroese: An overview and reference grammar. Tórshavn: Føroya Fróðskaparfelag.

ToIVOnEn, IDA. 2003. Non-projecting words: A case study of Swedish particles. Dordrecht: Kluwer.

Valfells, Sigrid, and James E. Cathey. 1981. Old Icelandic: An introductory course. Oxford: Oxford University Press.

VAN DE Velde, Freek. 2010. The emergence of the determiner in the Dutch NP. Linguistics 48.263-99. DOI: 10.1515/ling.2010.009.

VAN DE Velde, FreeK. 2011. Anaphoric adjectives becoming determiners. The noun phrase in Romance and Germanic, ed. by Petra Sleeman and Harry Perridon, 241-56. Amsterdam: John Benjamins. 
VAn Der Auwera, Johan. 1990. Coming to terms. Antwerp: University of Antwerp Habilitation thesis.

van Gelderen, Elly. 2004. Grammaticalization as economy. Amsterdam: John Benjamins.

van Gelderen, Elly. 2007. The definiteness cycle in Germanic. Journal of Germanic Linguistics 19.275-308. DOI: 10.1017/S147054270700013X.

VincEnT, Nigel. 1997. The emergence of the D-system in Romance. Parameters of morphosyntactic change, ed. by Ans van Kemenade and Nigel Vincent, 149-69. Cambridge: Cambridge University Press.

Vincent, Nigel. 1999. The evolution of c-structure: Prepositions and PPs from Indo-European to Romance. Linguistics 37.1111-53. DOI: 10.1515/ling.37.6.1111.

VINCENT, Nigel. 2001. LFG as a model of syntactic change. Time over matter: Diachronic perspectives on morphosyntax, ed. by Miriam Butt and Tracy Holloway King, 1-42. Stanford, CA: CSLI Publications.

VINCENT, Nigel. 2007. Learned vs popular syntax: Adjective placement in early Italian vernaculars. Languages of Italy: Histories and dictionaries, ed. by Anna Laura Lepschy and Arturo Tosi, 55-75. Ravenna: Longo.

vON FInTEL, KaI. 1995. The formal semantics of grammaticalization. North East Linguistic Society (NELS) 25.2.175-90.

Wallenberg, Joel C.; Anton Karl Ingason; Einar Freyr SigurĐsson; and Eiríkur RöGnvaldsson. 2011. Icelandic Parsed Historical Corpus (IcePaHC). Online: http:// www.linguist.is/icelandic_treebank/Icelandic_Parsed_Historical_Corpus_(IcePaHC).

WesséN, Elias. 1992. Svensk språkhistoria III grundlinjer till en historisk syntax: Nytryck $i$ nordiska språk och svenska. Edsbruk: Akademitryck.

YANG, Charles. 2010. Three factors in language variation. Lingua 120.160-77. DOI: 10 .1016/j.lingua.2008.09.015.

[kersti.borjars@manchester.ac.uk]

[pharries@uclan.ac.uk]

[nigel.vincent@manchester.ac.uk]
[Received 12 August 2013;

revision invited 5 February 2014; revision received 10 June 2015; accepted with revisions 30 June 2015; revision received 13 October 2015; accepted 18 October 2015] 